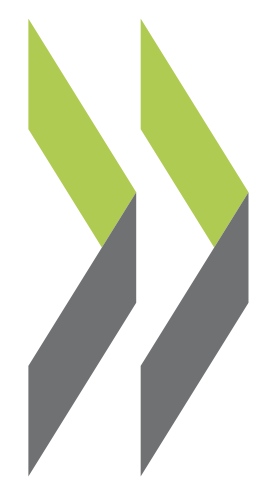

OECD Economics Department Working Papers No. 683

The Macroeconomic Consequences of Banking Crises in OECD Countries

\section{David Haugh,}

Patrice Ollivaud,

David Turner 
Organisation de Coopération et de Développement Économiques

Organisation for Economic Co-operation and Development

06-Mar-2009

ECONOMICS DEPARTMENT

English text only

THE MACROECONOMIC CONSEQUENCES OF BANKING CRISES IN OECD COUNTRIES

ECONOMICS DEPARTMENT WORKING PAPER No.683

by David Haugh, Patrice Ollivaud and David Turner

All Economics Department Working Papers are available through OECD's internet web site at www.oecd.org/eco/working_papers 


\section{ABSTRACT/RÉSUMÉ}

\section{The Macroeconomic Consequences of Banking Crises in OECD Countries}

This paper examines the characteristics of downturns and subsequent recoveries following past banking crises in OECD countries as well as evidence of any effects on potential output growth. It is differentiated from previous analyses because it makes use of OECD measures of the output gap and potential output. Downturns following banking crises are found to be more protracted with larger output losses and disproportionate falls in housing and business investment. The recovery is typically more muted with exports providing a disproportionately large positive contribution. Evidence regarding possible effects on potential growth of a banking crisis is mixed. The banking crisis in Japan was followed by a deterioration in potential growth partly due to a worsening in productivity performance which may be related to the protracted nature of the banking problems and the resulting misallocation of capital. Following the Nordic banking crises, which were resolved more quickly, there was no deterioration in productivity performance, although there was a temporary deterioration in potential growth which is mostly explained by an increase in the structural unemployment rate, which in turn may reflect the interaction of an exceptionally severe downturn with structural labour market rigidities.

Keywords: Banking crisis; financial crisis; downturn; output gap; business cycle; potential output. JEL classification: E32; E44.

******

\section{Conséquences macroéconomiques des crises bancaires dans les pays de l'OCDE}

Ce papier analyse, dans le contexte des crises bancaires passées des pays de l'OCDE, les caractéristiques des ralentissements économiques et de la reprise qui suit, ainsi que de mettre en évidence de possibles effets sur la croissance du potentiel de production. Cette étude se différencie des précédentes par l'utilisation de l'écart de production et du potentiel de l'économie. Les ralentissements qui font suite à une crise bancaire semblent durer plus longtemps avec des pertes plus importantes et avec une réaction négative de l'investissement privé disproportionnée. Le rythme de la reprise est plus modéré et se caractérise par des contributions fortement positives des exportations. Les résultats de l'analyse des conséquences des crises bancaires sur le potentiel de l'économie sont mitigés. La crise bancaire au Japon a affecté négativement le potentiel de production via une baisse de la productivité du travail. Cela peut être relié à la durée des problèmes bancaires qui ont touché le Japon et de leurs conséquences néfastes sur l'allocation du capital. Dans le cas des crises bancaires des pays nordiques qui ont duré moins longtemps, il n'y a pas eu d'effets sur la productivité, bien que temporairement le potentiel ait baissé ce qui provient principalement d'une augmentation du taux de chômage structurel. Cette dernière relation peut refléter l'interaction entre d'une part un ralentissement exceptionnellement sévère et d'autre part des rigidités structurelles sur le marché du travail.

Mots-clefs : Crise bancaire; crise financière; ralentissement économique; écart de production ; cycle économique ; croissance potentielle.

Classification JEL : E32; E44. 
Copyright $\odot$ OECD, 2009

Application for permission to reproduce or translate all, or part of, this material should be made to: Head of Publications Service, OECD, 2 rue André-Pascal, 75775 PARIS CEDEX 16, France. 


\section{TABLE OF CONTENTS}

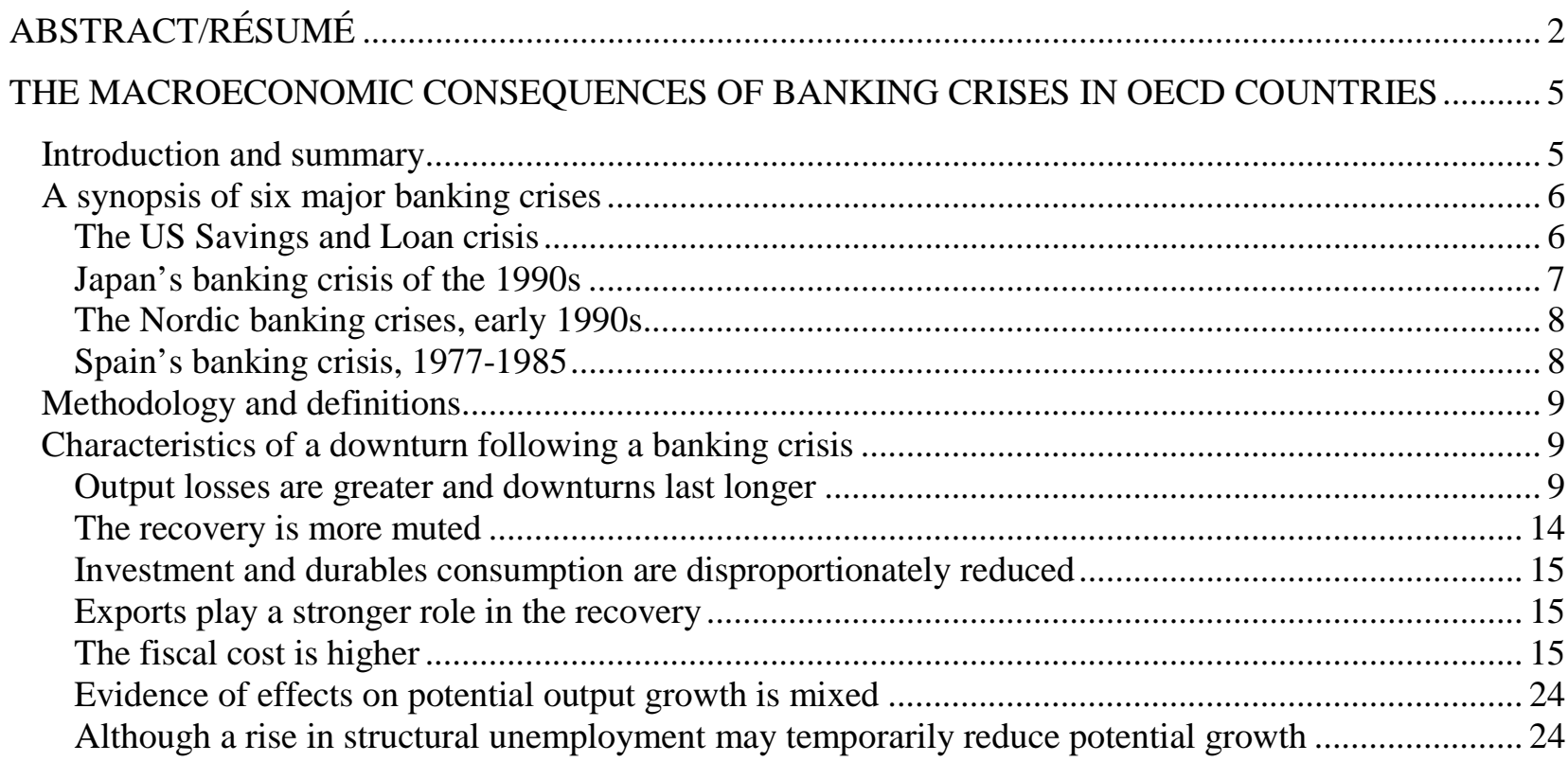

\section{Tables}

1. Downturns following banking crises

2. Recoveries following banking crises

3. Expenditure components following a banking crisis

4. $\quad$ Fiscal positions following a banking crisis

5. Potential growth following a banking crisis

\section{Figures}

1. Economic downturns following banking crises

2. Comparison of the downturns

3. Residential investment during downturns

4. $\quad$ Exports during downturns

5. Unemployment during a banking crisis downturn 
ECO/WKP(2009)24

\title{
THE MACROECONOMIC CONSEQUENCES OF BANKING CRISES IN OECD COUNTRIES
}

\author{
by
}

\author{
David Haugh, Patrice Ollivaud and David Turner ${ }^{1}$
}

\section{Introduction and summary}

1. In the wake of the financial crisis, the speed and synchronicity of the current downturn raises the prospect of the most severe global recession in post-war history. In order to provide some insight into the nature of the current downturn, this paper examines the characteristics of downturns and subsequent recoveries following past banking crises in OECD countries as well possible effects on potential output growth. It is differentiated from previous analyses because it makes use of OECD measures of the output gap and potential output. The banking crises considered are all severe enough to have a major macroeconomic impact, although this limits the number of episodes considered to just six. The main findings of the paper are that downturns following banking crises compared to other downturns have the following characteristics:

- Output losses are typically 2 to 3 times greater (and sometimes much more) and the period before output recovers back to capacity is at least twice as long.

- Business investment and particularly housing investment are disproportionately reduced in the downturn.

- The recovery, in terms of the extent of any bounce back from the trough of the downturn, is more muted.

- Exports tend to play a stronger role in the recovery, partly because of a larger depreciation of the exchange rate. There is also some evidence of a larger contribution from business investment, but not housing investment, during the recovery phase.

- There is a larger deterioration in the fiscal balance, typically falling by around 10 percentage points of GDP more to the trough of the downturn.

- Evidence regarding possible effects on potential growth of a banking crisis is mixed. Japan is the only case examined for which the downturn is followed by a permanent reduction in potential

1. Thanks to Sven Blondal and Jorgen Elmeskov for comments on an earlier draft, with the usual disclaimer. Thanks also to Lise Perreault for statistical support and Anne Eggimann for preparing the document. This paper extends and provides background material to an analysis first published in OECD Economic Outlook No.84. 
growth due to lower trend productivity growth, which may be related to the protracted nature of the banking problems which could have impaired the efficient allocation of capital.

- Following the Nordic banking crises, which were resolved more quickly, there was no deterioration in productivity performance. However, there was a temporary deterioration in potential growth which is mostly related to an increase in the structural unemployment rate, which in turn may reflect the interaction of an exceptionally severe downturn with structural labour market rigidities.

2. Given the global nature of the current financial crisis these findings would suggest that the current downturn is likely to be severe with output remaining below potential for many years. More speculatively, the findings suggest that potential output growth is more likely to be adversely affected due to weaker trend productivity growth, the longer it takes to resolve the immediate banking problems. In addition, structural unemployment may be more likely to increase (with negative implications for potential growth) the greater the extent of any structural weakness in labour markets, which are more likely to be exposed by a severe downturn. However, given the global nature of the present financial crisis, it is possible that there may be additional or different effects from those summarised above, where crises were confined to either only one major OECD economy or a group of smaller ones (the Nordics). On the one hand, the recovery may be even more muted because both export market growth and the scope for an exchange rate depreciation and subsequent gain in export market share are limited by the global nature of the downturn. On the other hand, the global nature of the downturn is inducing coordinated policy action which may provide positive externalities that a single country facing a banking crisis would not normally benefit from.

\section{A synopsis of six major banking crises}

3. Downturns following 6 major banking crises are examined. ${ }^{2}$ These are chosen as the "Big Five" banking crises identified by Rheinhart and Rogoff (2008) plus the Savings and Loan Crisis in the United States during the 1980s which Rheinhart and Rogoff refer to as being "just a notch below". The Big Five banking crises are Spain (1982), Finland, Norway and Sweden (all 1991) and Japan (1997). These dates coincide with the peak period of financial stress and are associated with extended periods of weak economic performance.

\section{The US Savings and Loan crisis}

4. In the United States the seeds of the Savings and Loans crisis were sown in the late 1970s and early 1980s. Heavy regulation of savings and loans institutions (thrifts) restricted them to lending on longterm fixed rate mortgages and imposed ceilings on the deposit rates they could pay. Rapidly rising inflation in the 1970s led to a major tightening of monetary policy in 1979 and consequent sharp rise in interest rates. Thrifts were hit by disintermediation as depositors sought better returns elsewhere and then later by large losses. Progressive removal of the deposit rate ceilings meant thrifts could attract funding again but only at rates above the largely fixed interest rates they were earning on the bulk of their mortgage portfolio. As a result many thrift institutions became insolvent.

5. The subsequent policy approach of regulatory forbearance policy response only served to aggravate the problems (Dotsey and Kupriavov, 1990). Accounting policies allowed insolvent institutions to give the appearance of solvency by valuing assets at historical rather than market value. In 1980 the

2. A banking crisis is regarded as being associated with a downturn if it occurs just before or during the downturn. The issue of the direction of causation between banking crises and downturns in the real economy is not directly examined here, but clearly causation may run in both directions. 
deposit guarantee limit was doubled to $\$ 100000$ and thrifts were allowed to diversify into consumer loans, property development and commercial loans. The deposit guarantee with a high limit allowed even insolvent thrifts to continue attracting deposits from indifferent depositors to use in risky projects in the hope of returning to solvency, which in turn led to mounting losses and increasingly severe insolvency problems. The regulatory authorities continued to show forbearance, hoping to avoid mass thrift closures and in any case lacking sufficient resources to wind up all of the insolvent thrift institutions. The crisis came to a climax in 1988 when the insolvent Federal Savings and Loans Deposit Insurance Corporation could no longer prop up the industry with its guarantees because private investors would no longer accept them. The number of failed thrifts rose to 200 in 1988 up from an average of around 50 per year throughout the 1980s. In 1989, the Federal government was forced to pass a clean-up package that far exceeded the likely cost of winding up insolvent thrifts even a few years earlier. Failures continued at high levels of around 300 in 1990 and 250 in 1991 (Warf and Cox, 1996). As the peak of the crisis occurred in the late 1980s, it is the subsequent downturn in the early 1990s that is treated as being associated with the crisis.

\section{Japan's banking crisis of the 1990s}

6. Regulatory forbearance also had a strong role in prolonging the 1990s banking crisis in Japan. The catalyst for the banking crisis was the collapse of the 1980s share and land price bubbles which peaked in 1989 and 1990 respectively. The collapse in land prices led to a rise in non-performing loans as construction and real estate companies stopped repaying their loans (Ito, 2003). In addition, Japanese banks had significant equity assets as part of a traditional system of cross-shareholdings and the fall in the sharemarket wiped out previous notable unrealised capital gains, $45 \%$ of which could be counted towards bank capital. Although the problem of bad loans was already obvious by 1992-1993 when the Jusen companies (non-bank housing loan companies) became insolvent, the authorities chose to adopt a wait-and-see approach. The proximate reason for the slow policy response was the large scale of the under-capitalisation and insolvency problems in the banking sector. This meant public money was necessary to resolve the problem and using taxpayers' money was not popular especially after a failed bail-out of the Jusen companies in 1995 (Fukao, 2003). Throughout the 1991-1997 period, weakened banks under-stated their bad loan problems in order to keep operating, but in so doing undermined investor confidence in Japanese accounting practices and financial statements. This lack of confidence forced Japanese banks to pay a premium in interbank borrowing markets. The crisis sharply escalated in late 1997 when a large bank and two large securities firms failed. Share prices of weaker institutions fell, mild bank-runs occurred and interbank lending further seized up. The resulting credit crunch led to falls in investment and a cutback in consumption which in turn fed into weaker growth and further cuts in credit. Because it was in 1997 that the crisis became full-blown, it is the downturn starting in that year stretching until the end of 2005 that is regarded as being associated with the crisis.

7. At the end of 1997, the government responded with a bailout package (6\% of GDP) to recapitalise solvent banks and protect depositors in failed banks. However, the package was not a success because only a small proportion of the funds were used and the government did not force the banks to write-off the bad loans (Fukao, 2003). In October 1998 with the failure of another large bank looming, the government doubled the size of the bailout package and quickly used it to nationalise two major banks and inject capital into 15 major banks. However, recovery of the sector was slow. Competition was distorted by extensive deposit insurance, regulatory forbearance in enforcing capital adequacy rules and lending growth requirements to the SME sector. This allowed even the worst banks to continue raising funds and meant lending standards were not always rigorously applied. An oversized banking sector, failure to develop new higher margin services, difficulty competing with money losing government lenders also helped contribute to a lack of profitability (Hoshi and Kashyap, 2004). This lack of profitability combined with ongoing increases in bad loans and a structural profitability problem meant the banking sector continued to run at an 
operating loss from 1992 until 2002. The sector only returned to profit again in 2003 when a low yen and strong trading partner growth helped put the economy back on an export-led growth path (Fukao, 2007).

\section{The Nordic banking crises, early 1990s}

8. In the Nordic countries, financial liberalisation coupled with weak prudential policies and a failure to adjust other policy settings appropriately led to a lending boom which eventually turned to bust in the face of falling asset prices, higher interest rates and external shocks. In Sweden, overly expansionary fiscal policy and strong lending growth following liberalisation of financial markets in the 1980s generated a boom in the economy and asset prices. The boom ended when asset markets turned and real interest rates rose sharply due to higher international interest rates, a tightening in monetary policy and tax changes (Englund, 1999). This led to borrower difficulties and eventually credit losses for banks large enough to threaten their solvency. System-wide loan loss provisions amounted to 12\% of GDP. These losses were exacerbated by the banks lack of experience in assessing credit risk in a more liberalised environment after a long period of being overly strictly regulated.

9. Financial markets were also liberalised in Finland in the 1980s but other policies were not aligned accordingly. The tax regime made borrowing very attractive to households and firms and no adjustments were made to reduce this strong incentive to borrow in order to offset the loss of restraint previously provided by credit rationing. In addition, fiscal and monetary policies were not set tight enough to appropriately restrain the extra demand impulse from liberalised credit markets (Nyberg and Vihriälä, 1993). This policy mix led to a credit and asset price boom in the late 1980s that was brought to an end when monetary policy was tightened in response to the boom and asset prices peaked and then declined sharply. The economy slowed sharply and this was compounded by weaker terms of trade as the forestry cycle turned and by the collapse of exports to the Soviet Union in 1991. As a result borrowers faced repayment difficulties and the banking system had to absorb mounting credit losses. As in Sweden, these losses were compounded by the both banks and borrowers being under-prepared to properly assess asset price, credit and interest and exchange rate risks that prevail in liberalised markets after a long period of regulation.

10. Norway liberalised its financial markets from 1984 to 1986 leading to a credit and asset price boom. The end of the boom came in 1987, earlier than in Finland and Sweden, following the sharp fall in oil prices in 1986. This led to a sharp reversal in asset prices and a downturn in the economy and rising bankruptcies. Bad loan losses first surfaced in the smaller banks which had engaged in risky lending practices but in 1990-1991 the three largest banks in Norway reported rising loan losses and difficulties in accessing wholesale funding markets (Ongena, Smith and Michalsen, 2000). This threatened the collapse of the entire banking system forcing the government to make large capital injections into the banks and to take control of several of them.

\section{Spain's banking crisis, 1977-1985}

11. The Spanish banking crisis ran its course from 1977 to 1985 and affected 52 out of the country's 110 banks, mostly small and medium-sized banks accounting for $20 \%$ of total deposits. Like the Nordic cases, it also had its roots in an inadequate policy mix to accompany the liberalisation of financial markets. The supervisory and regulatory regime was not appropriate for more liberalised markets -- information disclosure requirements were inadequate, the regulatory powers of the Bank of Spain were restricted, the law did not provide an appropriate basis for prosecuting wrongdoers and banking regulation was focussed on outmoded technical ratios (Sheng, 1996). As elsewhere, liberalisation allowed a rapid expansion of bank credit. In the Spanish case, credit was extended in particular to related financial and non-financial corporations. This increased the concentration of risk, obscured the true consolidated position of the banks and prolonged the provision of credit to shaky related borrowers where cross-shareholdings existed. The 
catalyst for the eventual banking crisis was the 1970s oil shocks, which had slowed the economy severely and under-mined the profitability and capacity of borrowers to repay loans. Widespread business failures eventually affected bank solvency and forced the government to recapitalise and restructure the banking industry.

\section{Methodology and definitions}

12. A distinguishing feature of the analysis presented here is that output losses during a downturn are measured in terms of the cumulative (negative) output gap, which is the cumulative loss in GDP relative to potential GDP, where the latter is the level of output which is estimated to be consistent with stable inflation. The use of potential output as a benchmark against which to assess output losses facilitates comparisons both across time and countries. It also has a conceptual attraction because even a severe slowdown in the growth rate of GDP may not be considered to have a macroeconomic cost if it brings output back to a level consistent with potential. For the purposes of this analysis a 'downturn' is defined as a period where actual GDP is below potential (i.e. the output gap is negative) for at least five consecutive quarters, with output falling at least $1 \%$ below potential and the cumulative output gap being at least $2 \%{ }^{3}$ Downturns associated with a banking crisis are compared with other downturns in the same country rather than comparing downturns across different countries in order to better control for cross-country heterogeneity in the degree of cyclicality in GDP.

\section{Characteristics of a downturn following a banking crisis}

\section{Output losses are greater and downturns last longer}

13. Business cycle downturns associated with banking crises are likely to be more severe than other downturns for a number of reasons: the supply of credit is substantially reduced either because of bank failures or because the erosion of bank capital forces banks to de-leverage (Bernanke, Lown and Friedman, 1991; Kashyap and Stein, 1991); large falls in the value of wealth typically associated with banking crises have negative effects on demand and also reduce the value of collateral which reduces the ability of households and firms to obtain credit (Bernanke and Gertler, 1995); and information asymmetries between lenders and borrowers become more acute, because of increased demand from a greater number of distressed borrowers, leading to a higher overall cost of capital (Bernanke and Gertler, 1987). Moreover, risks of a negative feedback loop between a deteriorating real economy and a further weakening of the banking sector are more severe.

14. The loss of output is greater for downturns associated with a banking crisis for all six countries the cumulative negative output gap tends to be between two to three times greater than for other downturns, although for Finland following the bank crisis of the early 1990s, the cumulative output loss was nearly eight times greater (Figures 1 and 2 and Table 1). In general, the greater output loss is due to the longer length of downturns across all countries and, in a majority of cases, a deeper trough in the output gap. Thus, for all six countries the downturns associated with a banking crisis (taken to be the number of quarters during which the output gap is negative) last longer, typically around seven to eight years, which is at least twice as long as other downturns experienced by the same country. For all downturns associated with a banking crisis, except Japan and the United States, the magnitude of the trough in the output gap is more severe than is typical for other downturns. These results are consistent with previous empirical work which finds that downturns preceded by banking crises tend to result both in larger GDP losses (Rogoff and Rheinhart, 2008; IMF, 2008) and last for longer (Rogoff and Rheinhart, 2008a).

3. Potential output and output gap measures are from the Economic Outlook 84 database. They are construction using a production function approach. See OECD Economic Outlook Methods (http://www.oecd.org/eco/sources-and-methods) for more details. 
Figure 1. Economic downturns following banking crises ${ }^{1}$

Output gaps, in percentage of potential output

United States

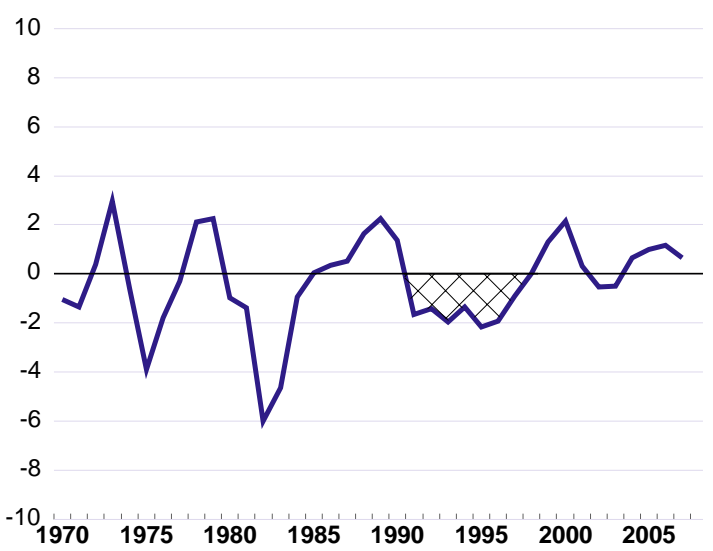

Spain

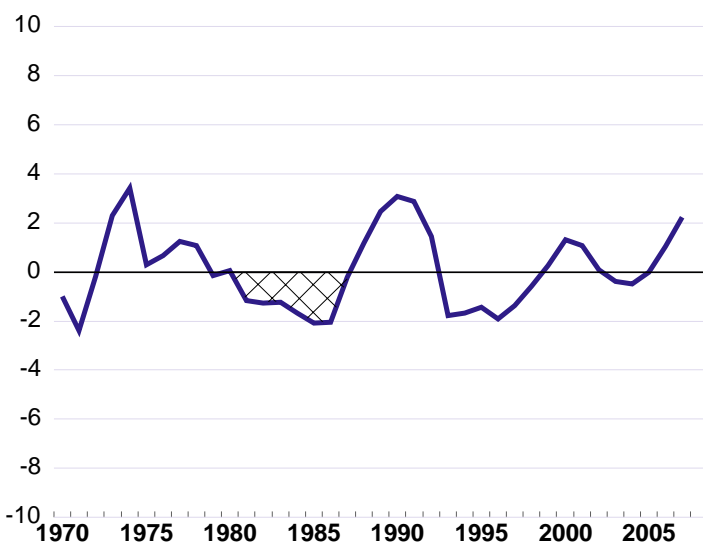

Norway

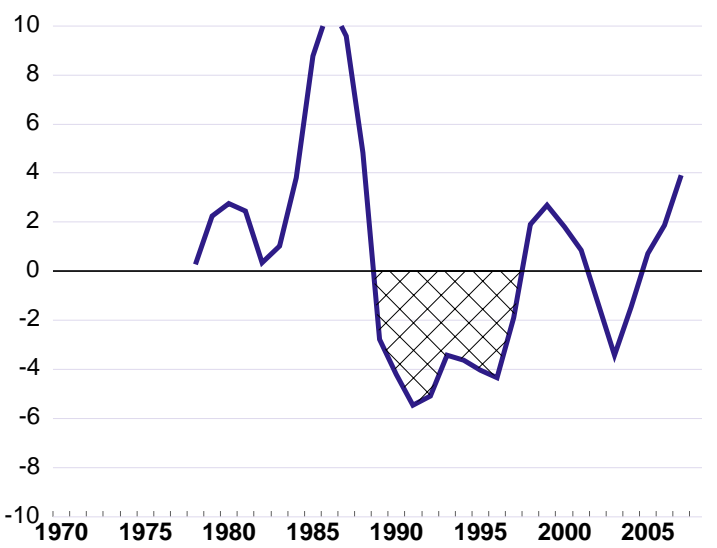

Japan

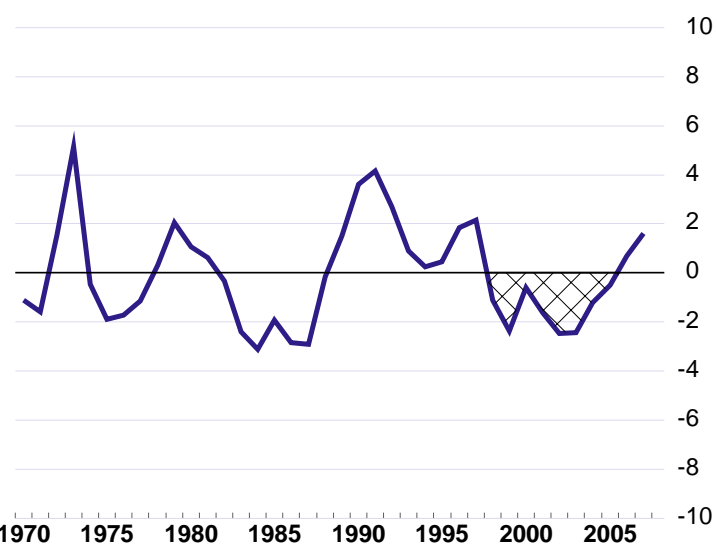

Finland

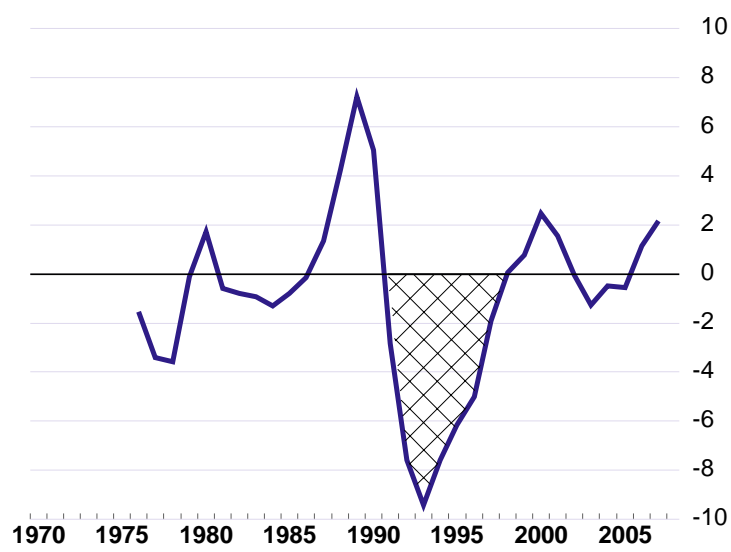

Sweden

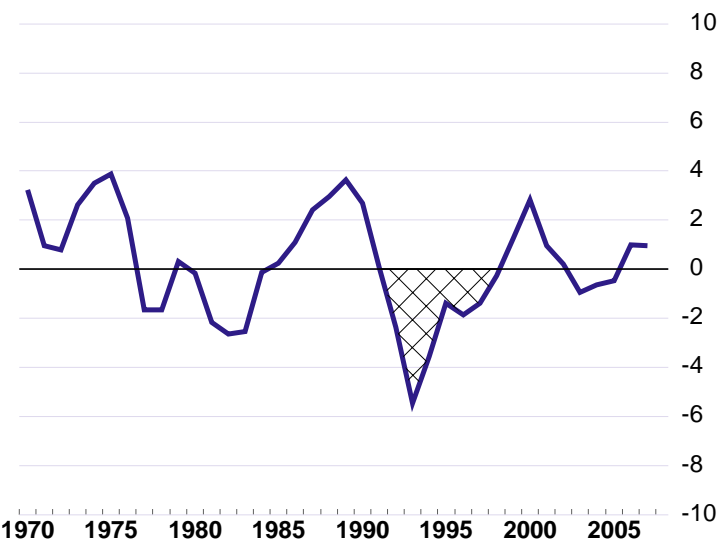

1. The downturn following a banking crisis is identified by the shaded area.

Source: OECD Economic Outlook 84 database. 


\section{Figure 2. Comparison of the downturns ${ }^{1}$}

Output gaps, in percentage of potential output

\section{a) United States}

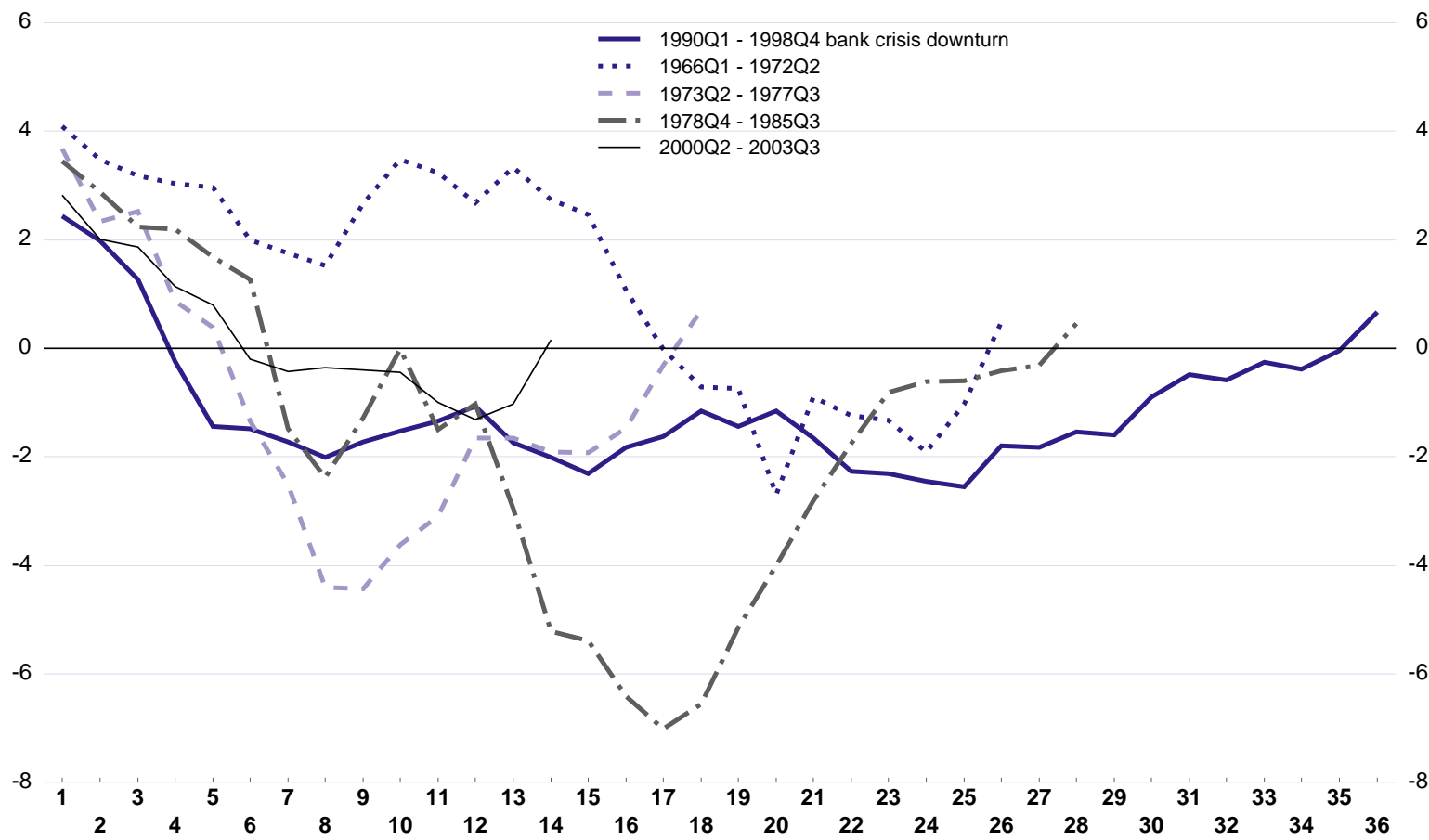

b) Japan

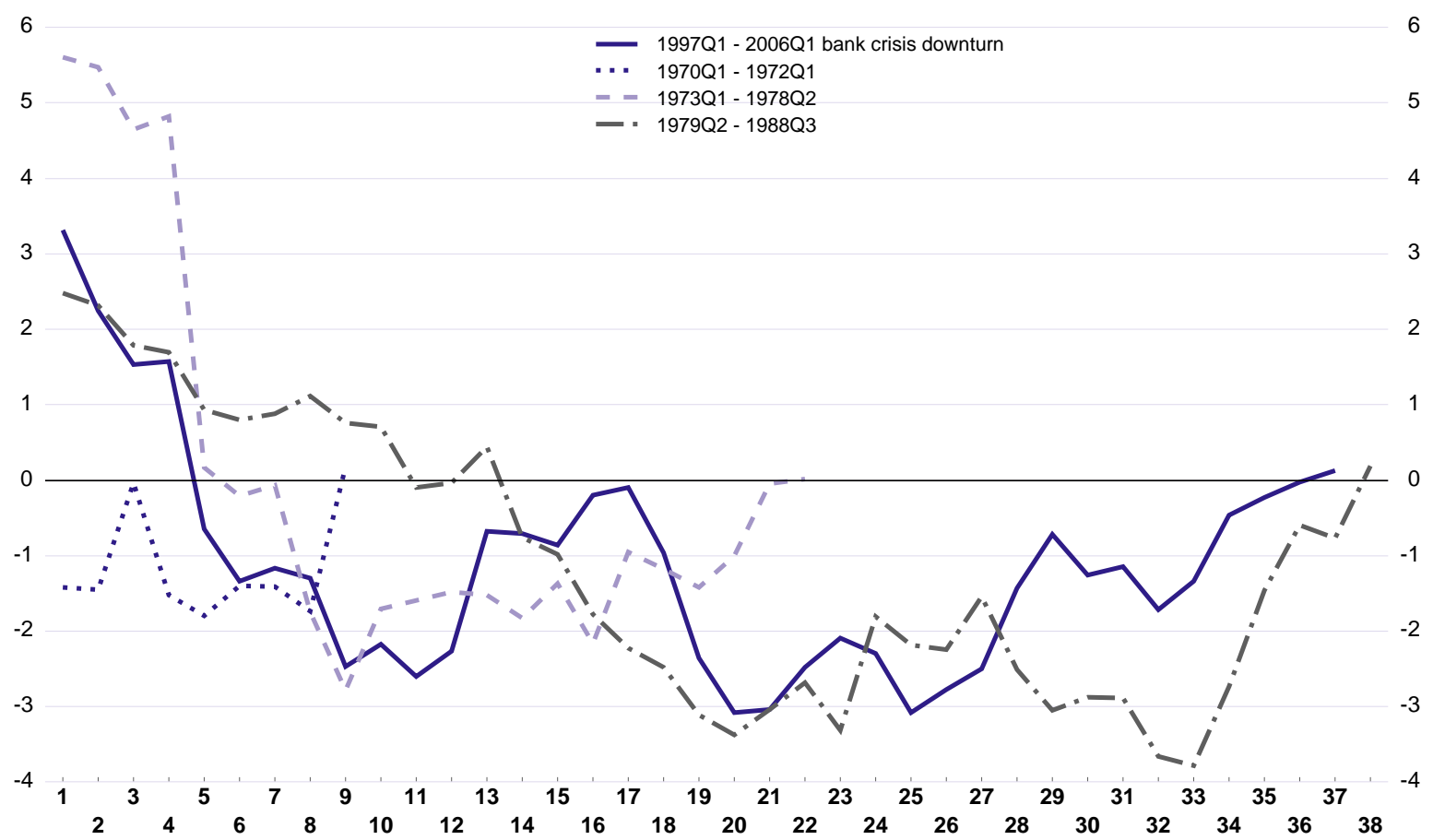

1. First quarter is taken to be peak output gap prior to the downturn.

Source: OECD Economic Outlook 84 database; and OECD calculations. 
Figure 2. Comparison of the downturns (cont'd)

Output gaps, in percentage of potential output

\section{c) Spain}

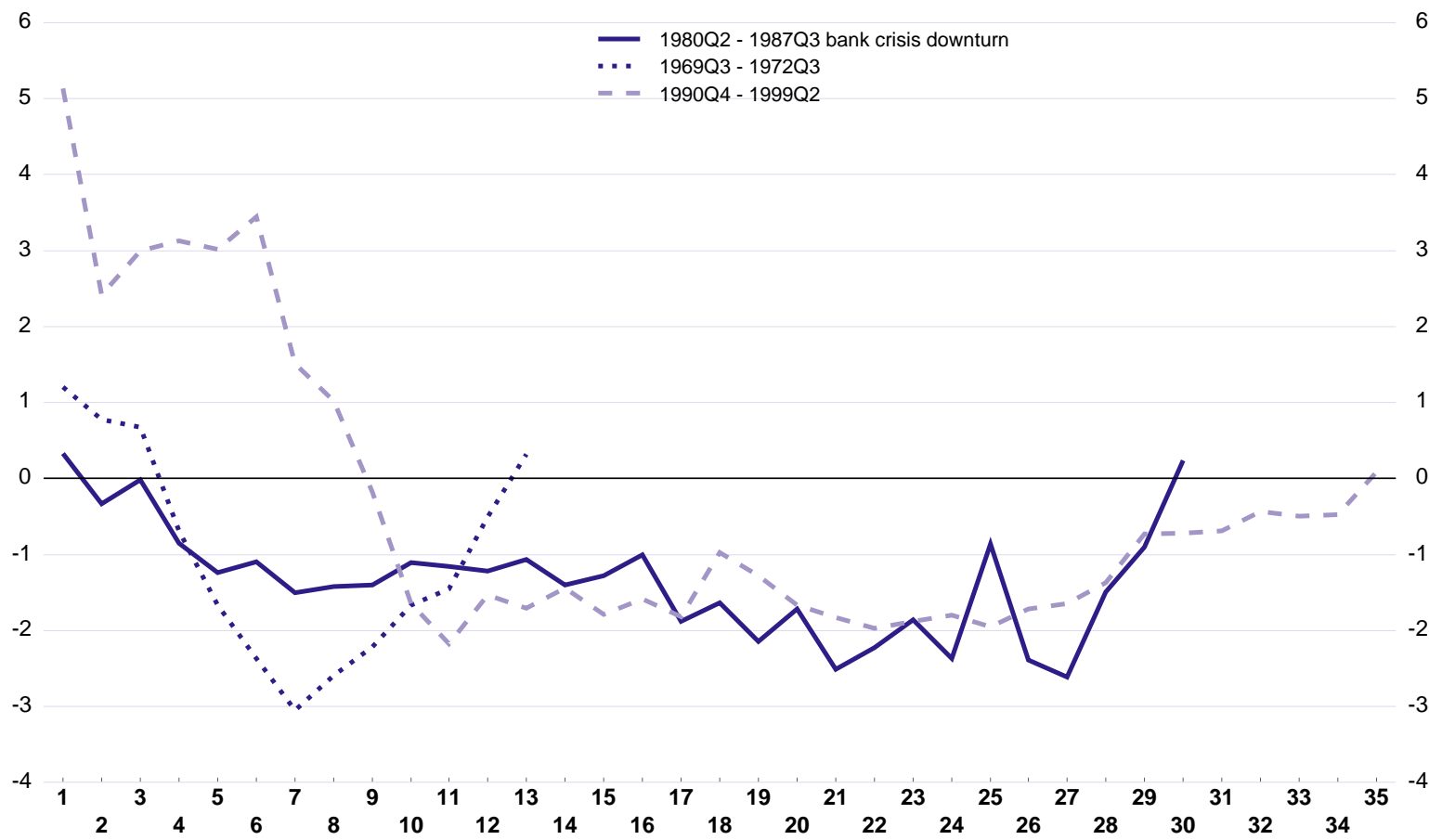

d) Finland

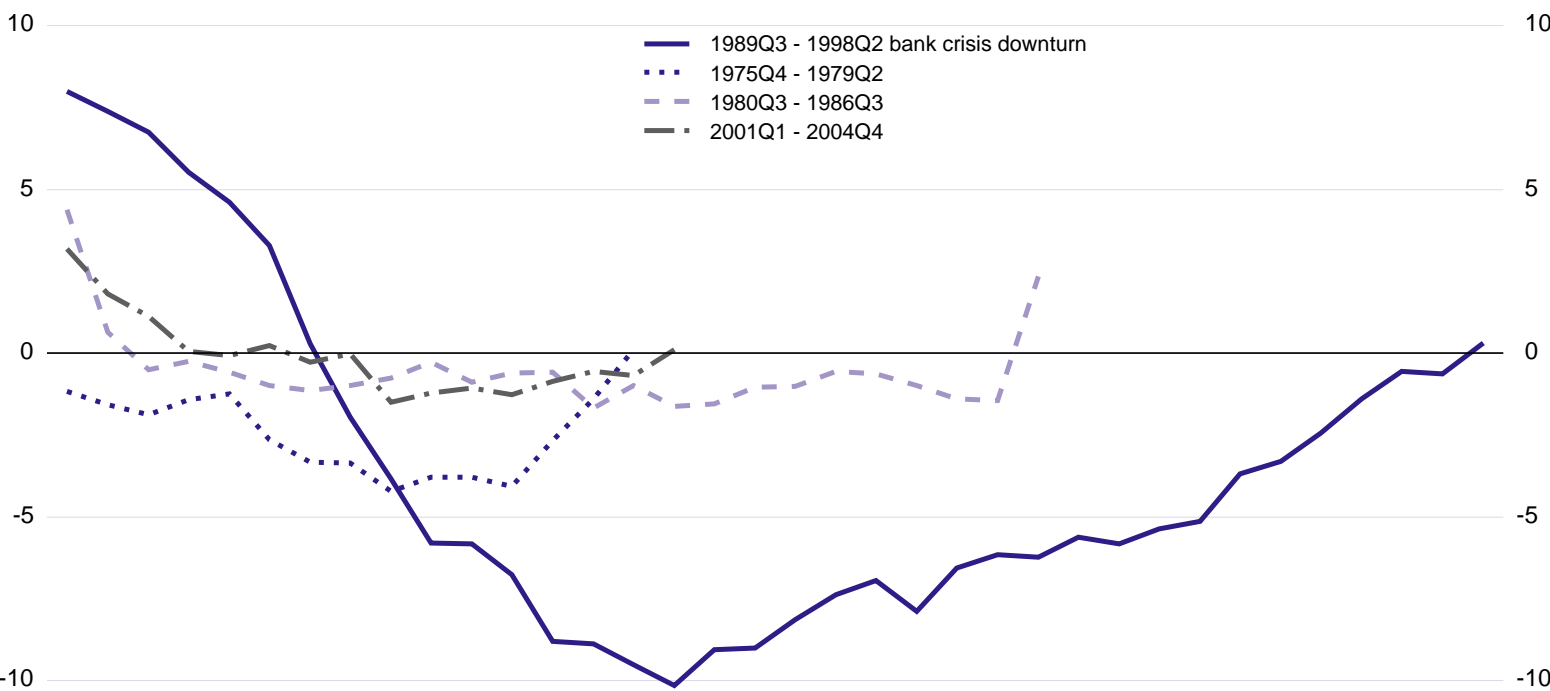

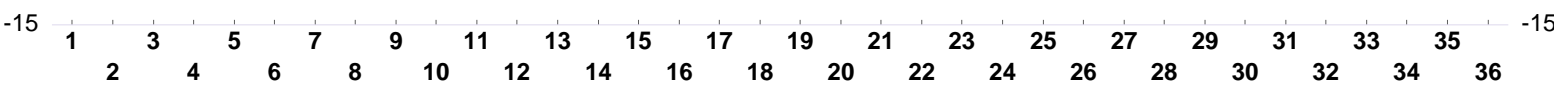

1. First quarter is taken to be peak output gap prior to the downturn.

Source: OECD Economic Outlook 84 database; and OECD calculations. 
Figure 2. Comparison of the downturns (cont'd)

Output gaps, in percentage of potential output

e) Norway

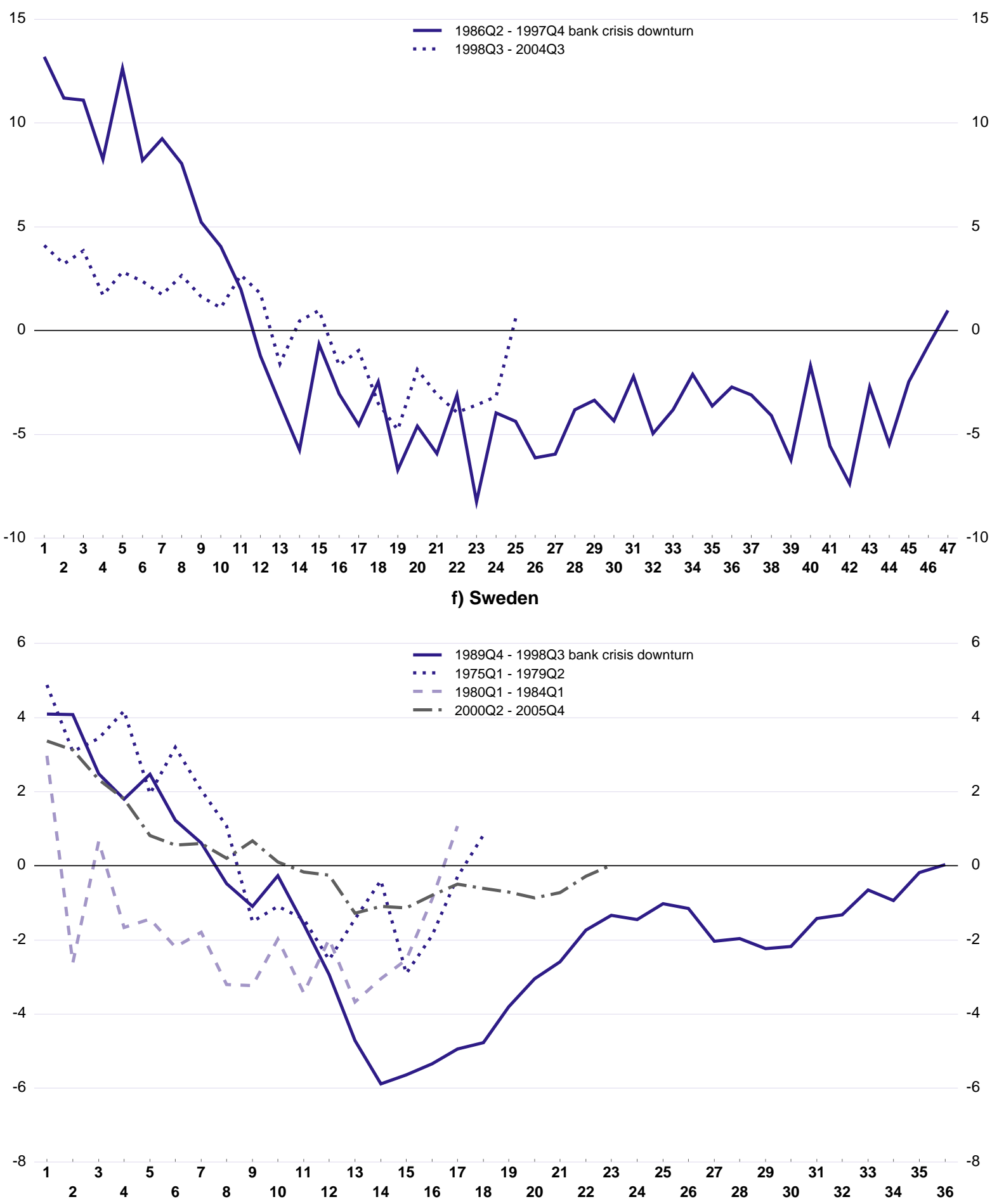

1. First quarter is taken to be peak output gap prior to the downturn.

Source: OECD Economic Outlook 84 database; and OECD calculations. 
Table 1. Downturns following banking crises

\begin{tabular}{|c|c|c|c|c|c|c|c|c|c|}
\hline & \multicolumn{3}{|c|}{$\begin{array}{l}\text { Duration of downturn } \\
\text { (quarters) }\end{array}$} & \multicolumn{3}{|c|}{$\begin{array}{l}\text { Trough in output gap } \\
\text { (\% of GDP) }\end{array}$} & \multicolumn{3}{|c|}{$\begin{array}{l}\text { Cumulative Output Loss } \\
(\% \text { pts of GDP) }\end{array}$} \\
\hline & Bank & Non-Bank & Ratio & Bank & Non-Bank & Ratio & Bank & Non-Bank & Ratio \\
\hline Spain & 28 & 12 & 2.3 & -2.6 & -3.4 & 0.8 & -10.1 & -6.0 & 1.7 \\
\hline United States & 32 & 13 & 2.6 & -2.6 & -3.9 & 0.7 & -11.4 & -6.2 & 1.8 \\
\hline Finland & 28 & 15 & 1.9 & -10.2 & -2.5 & 4.1 & -40.6 & -5.2 & 7.9 \\
\hline Japan & 32 & 16 & 2.0 & -3.1 & -2.8 & 1.1 & -12.3 & -7.3 & 1.7 \\
\hline Sweden & 28 & 11 & 2.5 & -5.9 & -2.6 & 2.2 & -16.7 & -4.3 & 3.9 \\
\hline Norway & 35 & 9 & 3.9 & -8.2 & -4.8 & 1.7 & -34.8 & -6.5 & 5.4 \\
\hline
\end{tabular}

Note: A downturn is defined as a period of at least two years when the cumulative output gap is at least $2 \%$ of GDP and output falls at least $1 \%$ below potential output in at least one year. Output gap measures are taken from the OECD Economic Outlook 84 database except for Spain where the output gap is derived by taking a Hodrick-Prescott filter of the GDP because the historical data for the standard output gap measure is too short for Spain.

1. Number of consecutive quarters for which output gap is negative.

Source: OECD Economic Outlook 84 database; and OECD calculations.

15. While a cumulative negative output gap might be expected to bring some macroeconomic benefit in terms of a reduced inflation rate, a more extreme negative output gap might give a proportionately smaller disinflationary effect (Turner, 1995). Moreover, a large and protracted negative output gap also raises the risk of deflation, as occurred in Japan.

\section{The recovery is more muted}

16. Output growth during the recovery phase, taken to be the period from the trough in the output gap to the period when the output gap is closed, is typically more muted following a banking crisis (Table 2). Thus measures of the "half-life" of the maximum output gap (i.e. the time taken for half the maximum output gap to close) is longer following a banking crisis, while the speed at which the output gap closes both initially (the first 6 quarters following the trough) and the average rate of change of the gap over the entirety of the recovery phase is usually (in four out of six cases) more sluggish.

Table 2. Recoveries following banking crises

\begin{tabular}{|c|c|c|c|c|c|c|c|c|c|}
\hline & \multicolumn{3}{|c|}{$\begin{array}{l}\text { Recovery Half Life } \\
\text { (quarters) }\end{array}$} & \multicolumn{3}{|c|}{$\begin{array}{l}\text { Change in the gap first six } \\
\text { quarters from trough }\end{array}$} & \multicolumn{3}{|c|}{$\begin{array}{l}\text { Average rate of change in the output } \\
\qquad \text { gap }^{2}\end{array}$} \\
\hline & Bank & Non-Bank & Ratio & Bank & Non-Bank & Ratio & Bank & Non-Bank & Ratio \\
\hline Spain & 2 & 4 & 0.5 & 0.6 & 0.6 & 1.0 & 0.9 & 0.6 & 1.7 \\
\hline United States & 5 & 3 & 2.0 & 0.3 & 0.6 & 0.6 & 0.3 & 0.6 & 0.5 \\
\hline Finland & 14 & 5 & 2.6 & 0.4 & 0.3 & 1.1 & 0.5 & 0.4 & 1.2 \\
\hline Japan & 3 & 4 & 0.8 & 0.3 & 0.5 & 0.6 & 0.3 & 0.5 & 0.5 \\
\hline Sweden & 7 & 3 & 2.3 & 0.5 & 0.5 & 0.9 & 0.3 & 0.9 & 0.3 \\
\hline Norway & 1 & 1 & 1.0 & 0.8 & 0.9 & 0.9 & 0.4 & 0.9 & 0.4 \\
\hline
\end{tabular}

1. The recovery half life is the number of quarters following the trough before the trough output gap is halved.

2. Average rate of change in the output gap between the trough until the output gap is closed.

Source: OECD Economic Outlook 84 database; and OECD calculations. 


\section{Investment and durables consumption are disproportionately reduced}

17. Components of aggregate expenditure which are most sensitive to credit conditions, particularly residential and business investment, are hardest hit during a downturn associated with a banking crisis, although causation is not unidrectional. This is evidenced by a generally larger fall in both categories of investment relative to the change in GDP over the period from the previous peak in the output gap to the trough during the downturn (Table 3 and Figures 3 and 4). While the fall in housing investment during the downturn following the Savings and Loan crisis in the United States appears to be an exception, this is only because the greatest fall in housing investment is not coincident with the trough in the output gap. Indeed, the share of residential investment in GDP was unusually low (relative to the long-run historical average) for most of the duration of the downturn.

18. Residential investment also makes a smaller contribution to the recovery phase following a banking crisis than it does during other recovery phases. In contrast, business investment tends to recover more strongly than normal relative to GDP in the recovery phase following the trough.

19. Evidence from the United States, where the data are available for a sufficiently long period, suggests that durables consumption is weaker relative to GDP in a downturn associated with a banking crisis and it takes longer for durables consumption to recover again relative to GDP. ${ }^{4}$

\section{Exports play a stronger role in the recovery}

20. For countries with an independent floating exchange rate, exports have a potentially more important role in helping the economy exit from a bank crisis associated downturn. Export market growth usually remains much stronger than domestic market growth. Furthermore, the export sector tends to be dominated by larger firms with less reliance on the domestic banking sector than other sectors such as construction, which may normally have a stronger role in recovery. Indeed, in all six countries net exports grew more strongly relative to the change GDP in the recovery following the trough (Table 3). For all of the banking crisis downturns, with the exception of Spain, there was a substantial depreciation in the real effective exchange rate of a greater magnitude than experienced during other downturns.

\section{The fiscal cost is higher}

21. The negative implications for the fiscal position tend to be greater for a downturn which follows a banking crisis. With the exception of the United States, the fiscal balance deteriorated by more during the bank crisis associated downturns, usually falling by around 10 percentage points of GDP more from the peak to the trough of the cycle (Table 4). Gross public debt also increases by considerably more from the peak to the trough of the cycle, although the exact amount is quite variable from 10 percentage points extra in the United States to 44 percentage points in the Japanese case. Some of this greater deterioration in the fiscal position can be attributed to the stronger downturn in the economy. Nevertheless, even the cyclically adjusted balance generally deteriorates by more in a bank-crisis associated downturn. This may be due to the extra fiscal costs associated with bank bail-outs and also use of discretionary fiscal policy in bank-crisis associated downturns. In the recovery phase from the trough to a zero output gap, there tends to be a stronger consolidation effort, particularly on the expenditure side most notably in the case of all three Nordic countries, and the fiscal balance improves by considerably more. Despite this greater consolidation effort, gross public debt still rose by more in the recovery phase than for a typical recovery.

4. The maximum difference between the percentage change in the level of consumer durables and GDP in the period subsequent to when the output gap peaks is greater than the non-bank crisis average and it takes longer for the consumer durables to outperform GDP in growth terms again (consumer durables is a more volatile series than GDP). The early 1980s recession is excluded as part of the non-bank crises period control group in this comparison as it is affected by the imposition of credit controls which had a marked affect on consumer credit and durables consumption. Indeed this episode provides further evidence that a banking crisis which restricts consumer credit is likely to hit consumer durables expenditure particularly hard. 
Table 3. Expenditure components following a banking crisis Peak to Trough Output Gap

\begin{tabular}{|c|c|c|c|c|c|c|c|c|c|}
\hline & $\begin{array}{l}\text { Resi } \\
\text { Bank crisis } \\
\text { downturn }\end{array}$ & $\begin{array}{l}\text { dential invest } \\
\text { Average of } \\
\text { other } \\
\text { downturns }\end{array}$ & Difference & $\begin{array}{r}\text { Bu } \\
\text { Bank crisis } \\
\text { downturn }\end{array}$ & $\begin{array}{l}\text { iness investn } \\
\text { Average of } \\
\text { other } \\
\text { downturns }\end{array}$ & Difference & $\begin{array}{l}\text { Bank crisis } \\
\text { downturn }\end{array}$ & $\begin{array}{l}\text { Consumption } \\
\text { Average of } \\
\text { other } \\
\text { downturns }\end{array}$ & Difference \\
\hline Spain & -49.9 & 5.2 & -55.1 & -21.7 & -9.4 & -12.3 & -1.5 & 1.2 & -2.7 \\
\hline United States & 0.7 & -19.4 & 20.2 & 17.1 & -7.3 & 24.4 & 1.7 & 4.4 & -2.7 \\
\hline Finland & -31.0 & -1.0 & -30.0 & -37.7 & -3.1 & -34.6 & -0.1 & 5.2 & -5.3 \\
\hline Japan & -41.4 & -21.8 & -19.6 & -30.0 & 10.7 & -40.7 & 7.8 & 1.5 & 6.3 \\
\hline Sweden & -28.0 & 2.3 & -30.4 & -40.5 & -9.7 & -30.9 & -1.2 & 1.1 & -2.3 \\
\hline Norway & -54.4 & 15.4 & -69.9 & -37.5 & -25.0 & -12.5 & -10.0 & 5.3 & -15.3 \\
\hline & $\begin{array}{l}\text { Bank crisis } \\
\text { downturn }\end{array}$ & $\begin{array}{c}\text { Exports } \\
\text { Average of } \\
\text { other } \\
\text { downturns }\end{array}$ & Difference & $\begin{array}{l}\text { Bank crisis } \\
\text { downturn }\end{array}$ & $\begin{array}{c}\text { Imports } \\
\text { Average of } \\
\text { other } \\
\text { downturns }\end{array}$ & Difference & $\begin{array}{l}\text { Bank crisis } \\
\text { downturn }\end{array}$ & $\begin{array}{l}\text { ective Exchang } \\
\text { Average of } \\
\text { other } \\
\text { downturns }\end{array}$ & e Rate \\
\hline Spain & 88.8 & 48.9 & 39.9 & 40.6 & 10.0 & 30.5 & 7.6 & -10.1 & 17.7 \\
\hline United States & 35.3 & 4.8 & 30.5 & 30.8 & 23.6 & 7.2 & -3.2 & 9.8 & -13.0 \\
\hline Finland & 32.4 & -0.1 & 32.4 & -4.9 & 8.1 & -13.0 & -28.5 & 4.8 & -33.3 \\
\hline Japan & 48.1 & 23.6 & 24.4 & 45.1 & 0.0 & 45.1 & 7.4 & 20.6 & -13.2 \\
\hline Sweden & 10.6 & 8.1 & 2.5 & -5.8 & 9.4 & -15.2 & -7.7 & -9.1 & 1.4 \\
\hline Norway & 43.9 & 1.9 & 42.0 & -12.5 & 15.6 & -28.1 & -1.9 & 17.1 & -19.0 \\
\hline
\end{tabular}

\section{Trough to Zero Output Gap}

\begin{tabular}{|c|c|c|c|c|c|c|c|c|c|}
\hline & $\begin{array}{l}\text { Resi } \\
\text { Bank crisis } \\
\text { downturn }\end{array}$ & $\begin{array}{l}\text { Average of } \\
\text { other } \\
\text { downturns }\end{array}$ & Difference & $\begin{array}{l}\text { Bus } \\
\text { Bank crisis } \\
\text { downturn }\end{array}$ & $\begin{array}{l}\text { iness investn } \\
\text { Average of } \\
\text { other } \\
\text { downturns }\end{array}$ & Difference & $\begin{array}{l}\text { Bank crisis } \\
\text { downturn }\end{array}$ & $\begin{array}{c}\text { Consumption } \\
\text { Average of } \\
\text { other } \\
\text { downturns }\end{array}$ & Difference \\
\hline Spain & 0.1 & 5.9 & -5.7 & 9.9 & 22.1 & -12.2 & -1.8 & -1.9 & 0.2 \\
\hline United States & 4.0 & 30.6 & -26.6 & 21.8 & 5.2 & 16.5 & -0.4 & -0.9 & 0.5 \\
\hline Finland & -1.6 & -8.3 & 6.7 & 26.1 & -6.5 & 32.6 & -6.6 & -1.1 & -5.5 \\
\hline Japan & -4.4 & 7.3 & -11.6 & 12.4 & -4.0 & 16.5 & -2.8 & -2.2 & -0.6 \\
\hline Sweden & -74.3 & 6.8 & -81.1 & 75.1 & 5.8 & 69.4 & -6.0 & -3.3 & -2.6 \\
\hline Norway & 21.5 & 16.5 & 5.0 & 21.7 & -2.7 & 24.4 & -6.6 & 2.6 & -9.2 \\
\hline & $\begin{array}{l}\text { Bank crisis } \\
\text { downturn }\end{array}$ & $\begin{array}{c}\text { Exports } \\
\text { Average of } \\
\text { other } \\
\text { downturns }\end{array}$ & Difference & $\begin{array}{l}\text { Bank crisis } \\
\text { downturn }\end{array}$ & $\begin{array}{l}\text { Imports } \\
\text { Average of } \\
\text { other } \\
\text { downturns }\end{array}$ & Difference & $\begin{array}{l}\text { Real Eff } \\
\text { Bank crisis } \\
\text { downturn }\end{array}$ & $\begin{array}{l}\text { ective Exchan } \\
\text { Average of } \\
\text { other } \\
\text { downturns }\end{array}$ & e Rate \\
\hline Spain & -0.8 & 17.7 & -18.5 & 10.2 & 41.6 & -31.4 & 1.6 & -0.3 & 1.9 \\
\hline United States & 8.0 & -3.4 & 11.5 & 23.8 & 16.0 & 7.8 & 12.4 & -1.0 & 13.4 \\
\hline Finland & 42.0 & 5.6 & 36.5 & 35.7 & 5.2 & 30.6 & -28.6 & -1.7 & -26.9 \\
\hline Japan & 27.3 & 4.4 & 22.9 & 10.1 & 2.9 & 7.2 & -11.3 & 16.1 & -27.4 \\
\hline Sweden & 53.5 & 8.8 & 44.7 & 44.7 & 6.4 & 38.3 & -6.3 & -1.0 & -5.2 \\
\hline Norway & 13.4 & -2.2 & 15.6 & 10.5 & 6.0 & 4.5 & -3.1 & -10.9 & 7.8 \\
\hline
\end{tabular}

Note: All figures are reported as the difference between the percentage change in the component and the percentage change in GDP. Except for the real exchange rate where the percentage change is reported. The top of the table analyses changes from the time of the peak output gap prior to the downturn until the trough in the output gap during the downturn. The lower half analyses the changes from the trough of the downturn to the time the output gap is closed again.

Source: OECD Economic Outlook 84 database; and OECD calculations. 
Figure 3. Residential investment during downturns'

\section{a) United States}

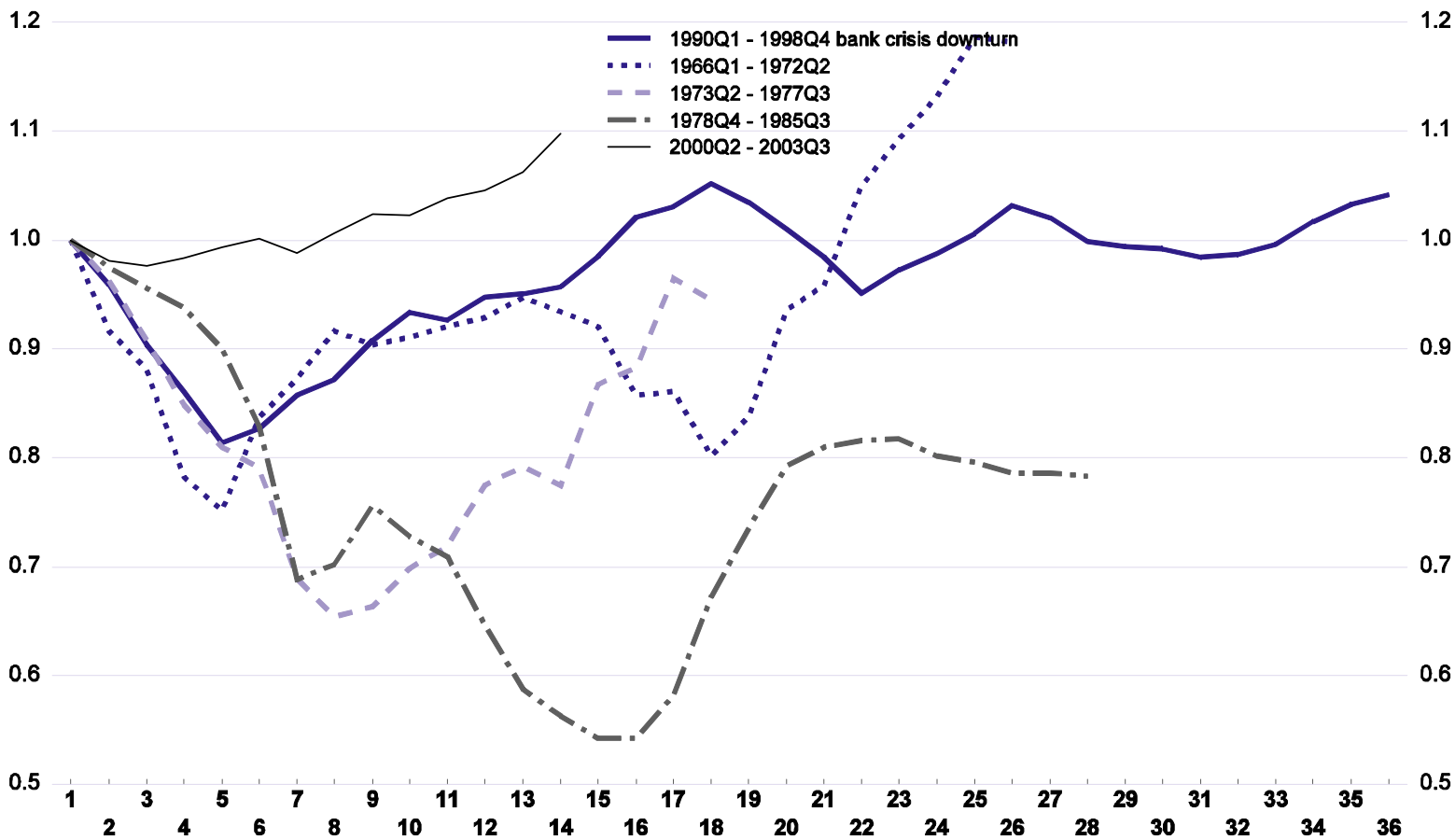

b) Japan

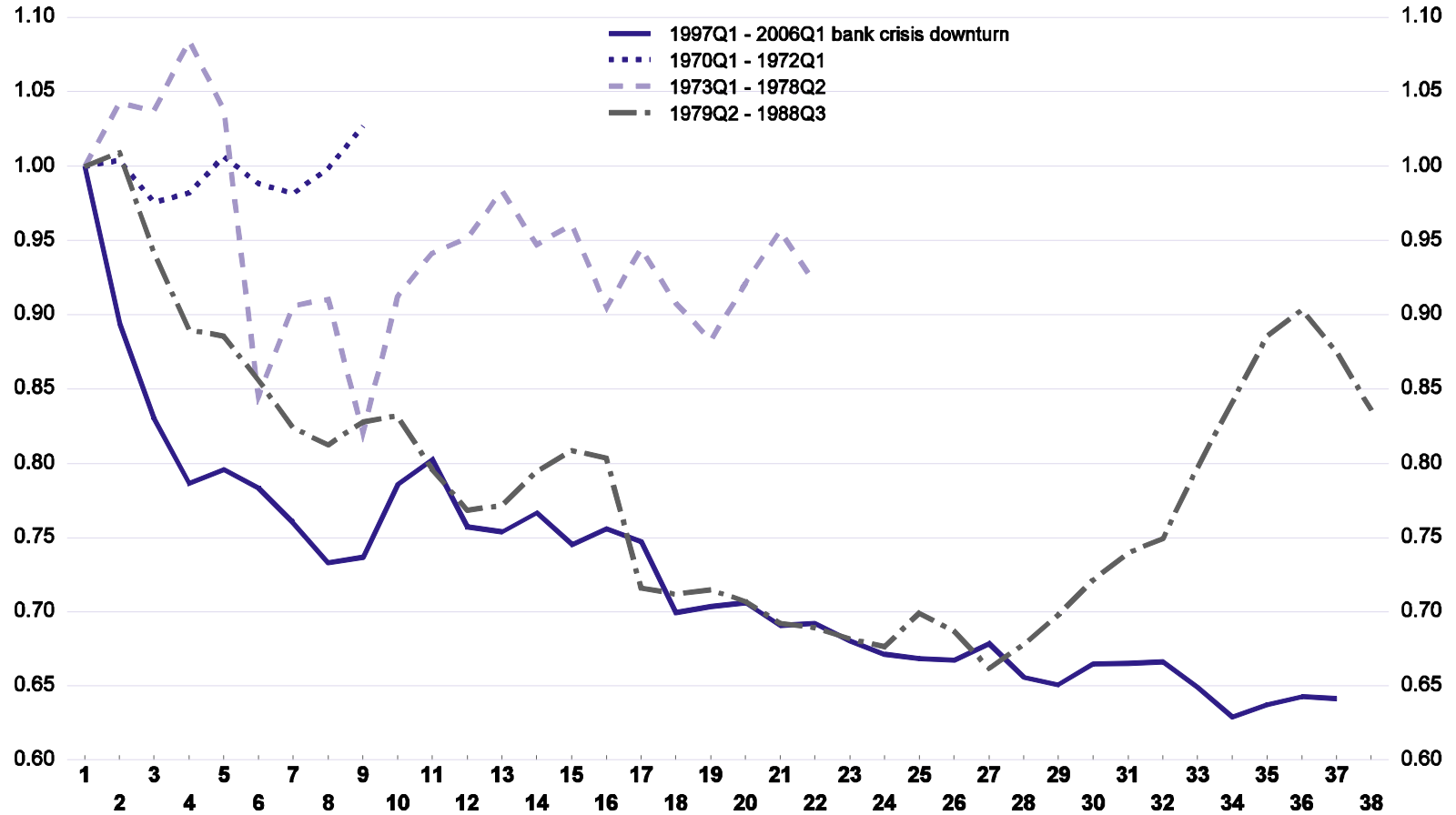

1. Real residential investment relative to real GDP, normalised so that this ratio equals unity at the cyclical peak prior to the downturn.

Source: OECD Economic Outlook 84 database. 
Figure 3. Residential investment during downturns' ${ }^{1}$ (cont'd)

\section{c) Spain}
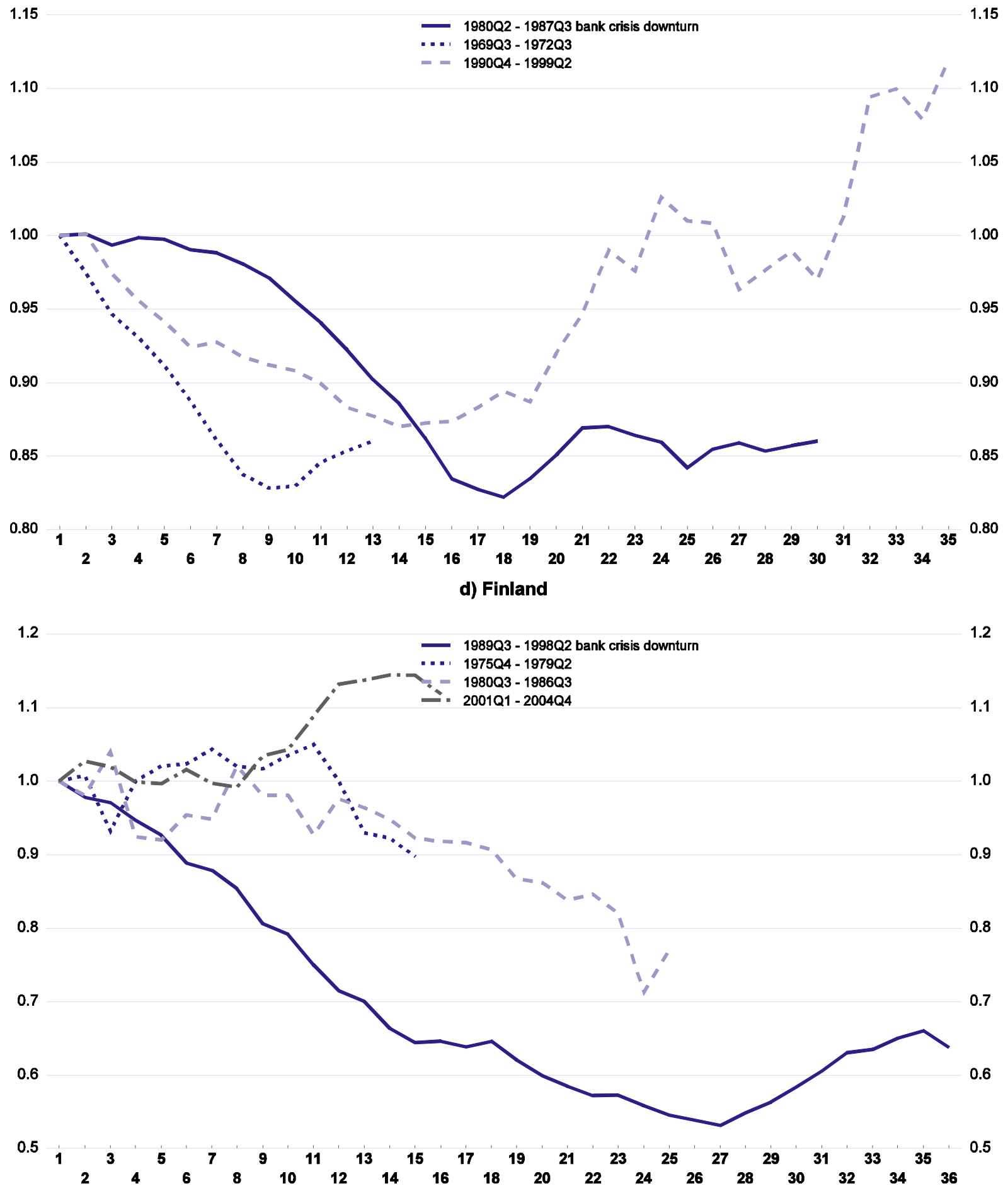

1. Real residential investment relative to real GDP, normalised so that this ratio equals unity at the cyclical peak prior to the downturn.

Source: OECD Economic Outlook 84 database. 
Figure 3. Residential investment during downturns' ${ }^{1}$ (cont'd)

\section{e) Norway}

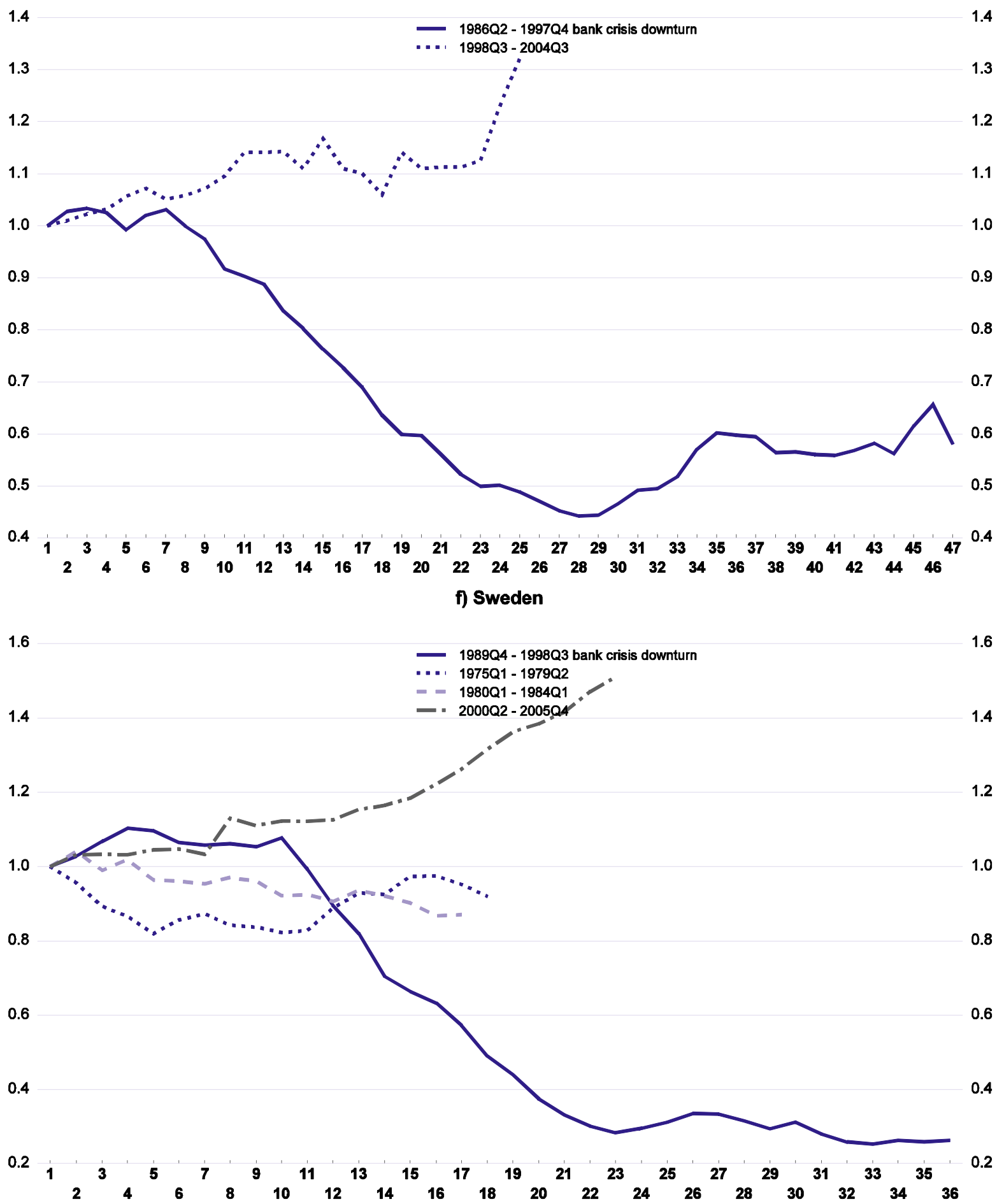

1. Real residential investment relative to real GDP, normalised so that this ratio equals unity at the cyclical peak prior to the downturn.

Source: OECD Economic Outlook 84 database. 
Figure 4. Exports during downturns ${ }^{1}$

\section{a) United States}

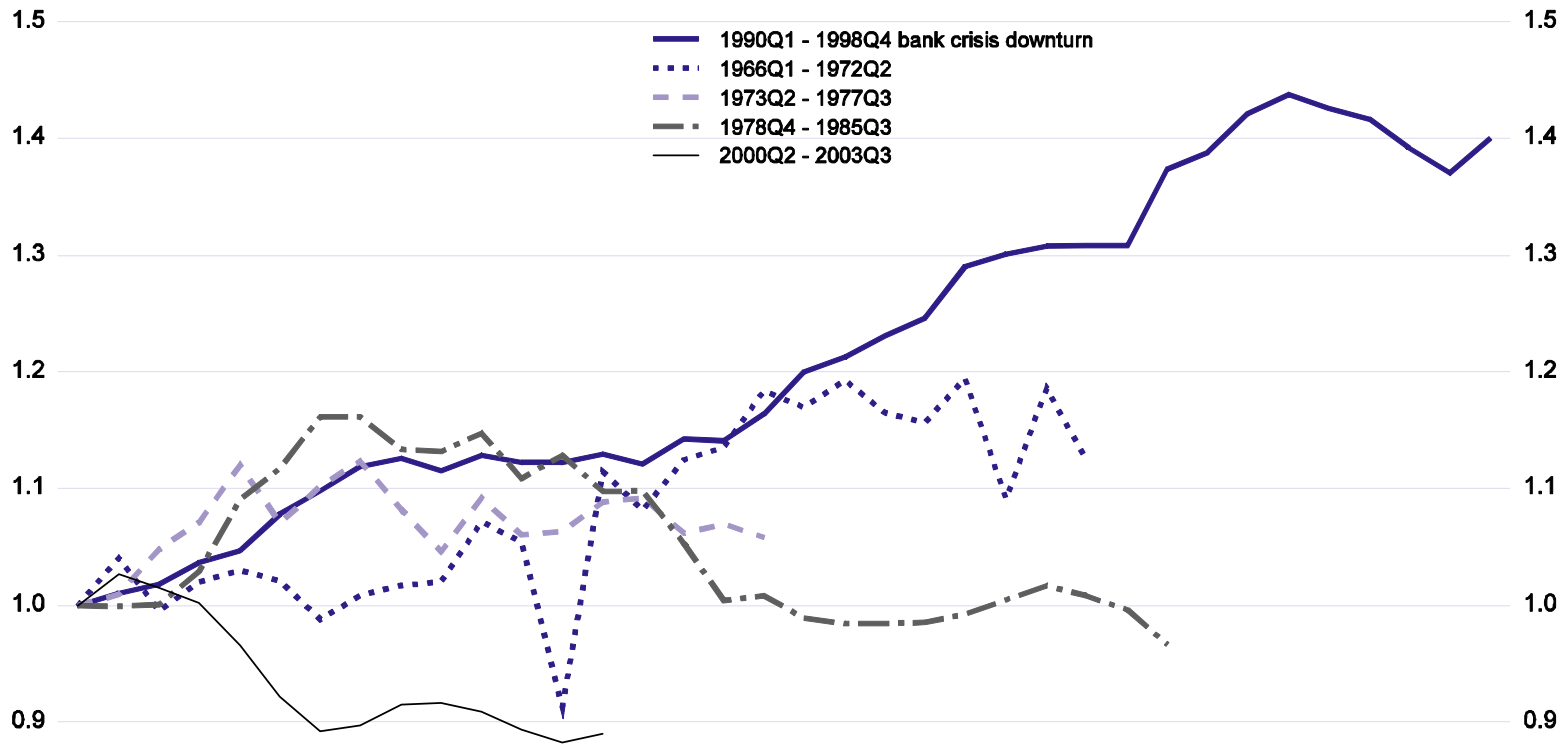

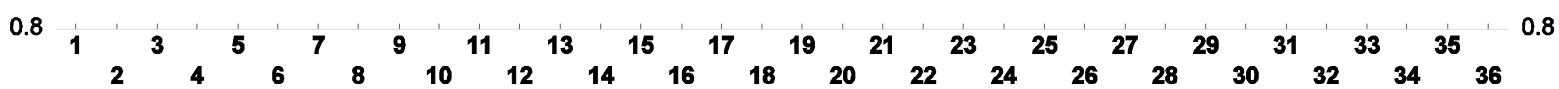
b) Japan

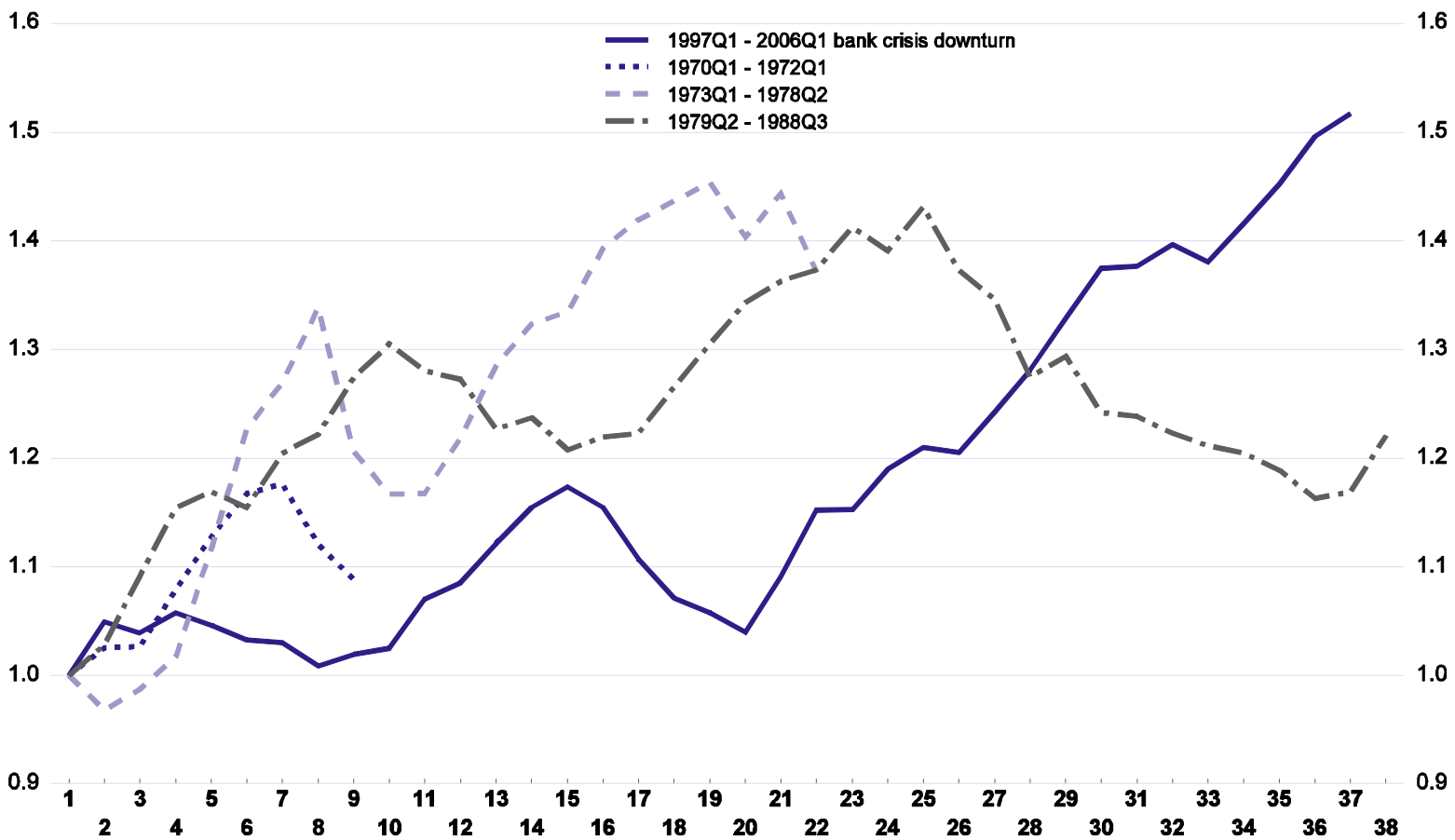

1. Real export relative to real GDP, normalised so that this ratio equals unity at the cyclical peak prior to the downturn. Source: OECD Economic Outlook 84 database. 
Figure 4. Exports during downturns ${ }^{1}$ (cont'd)

\section{c) Spain}

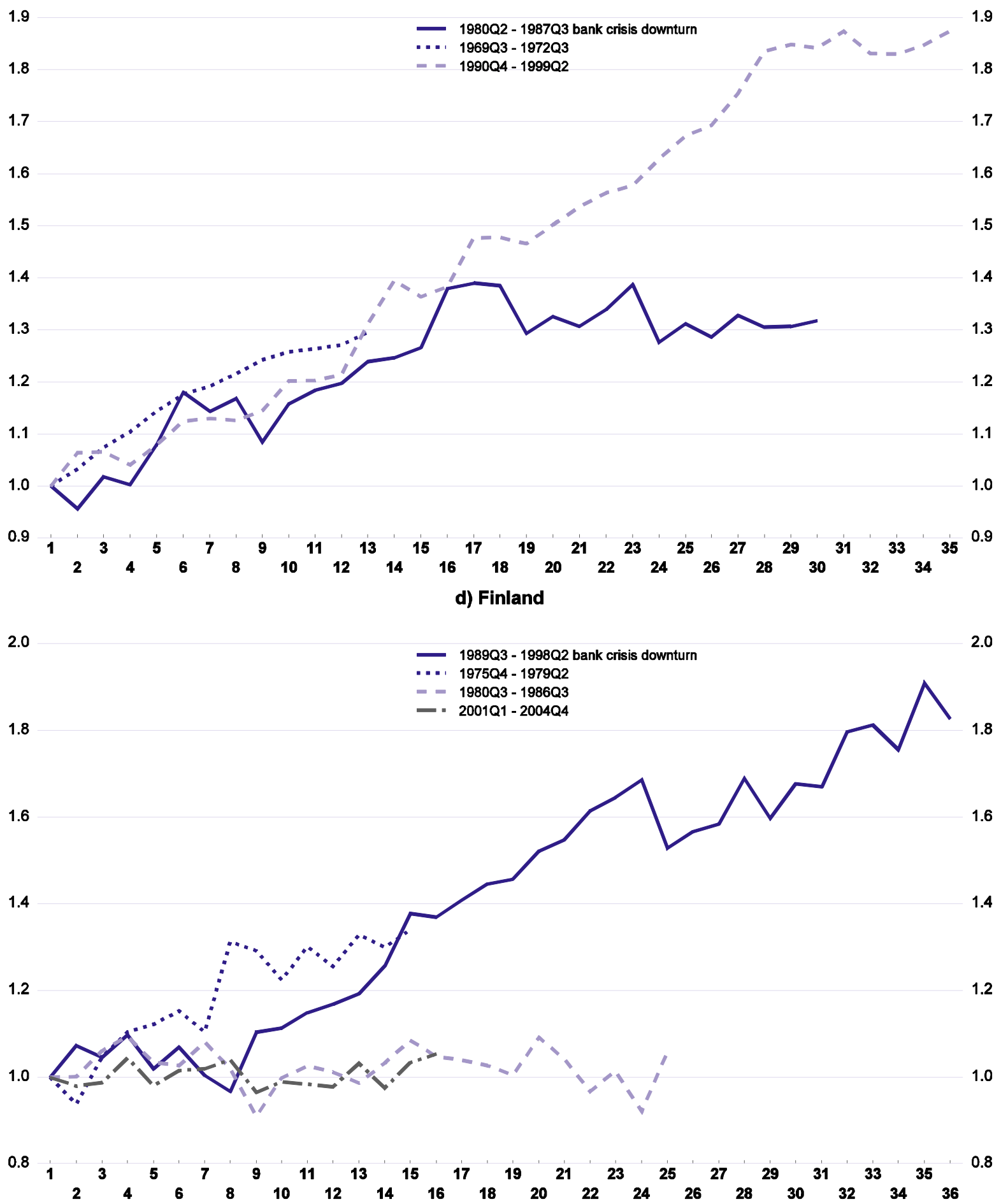

1. Real export relative to real GDP, normalised so that this ratio equals unity at the cyclical peak prior to the downturn. Source: OECD Economic Outlook 84 database. 
Figure 4. Exports during downturns ${ }^{1}$ (cont'd)

\section{e) Norway}

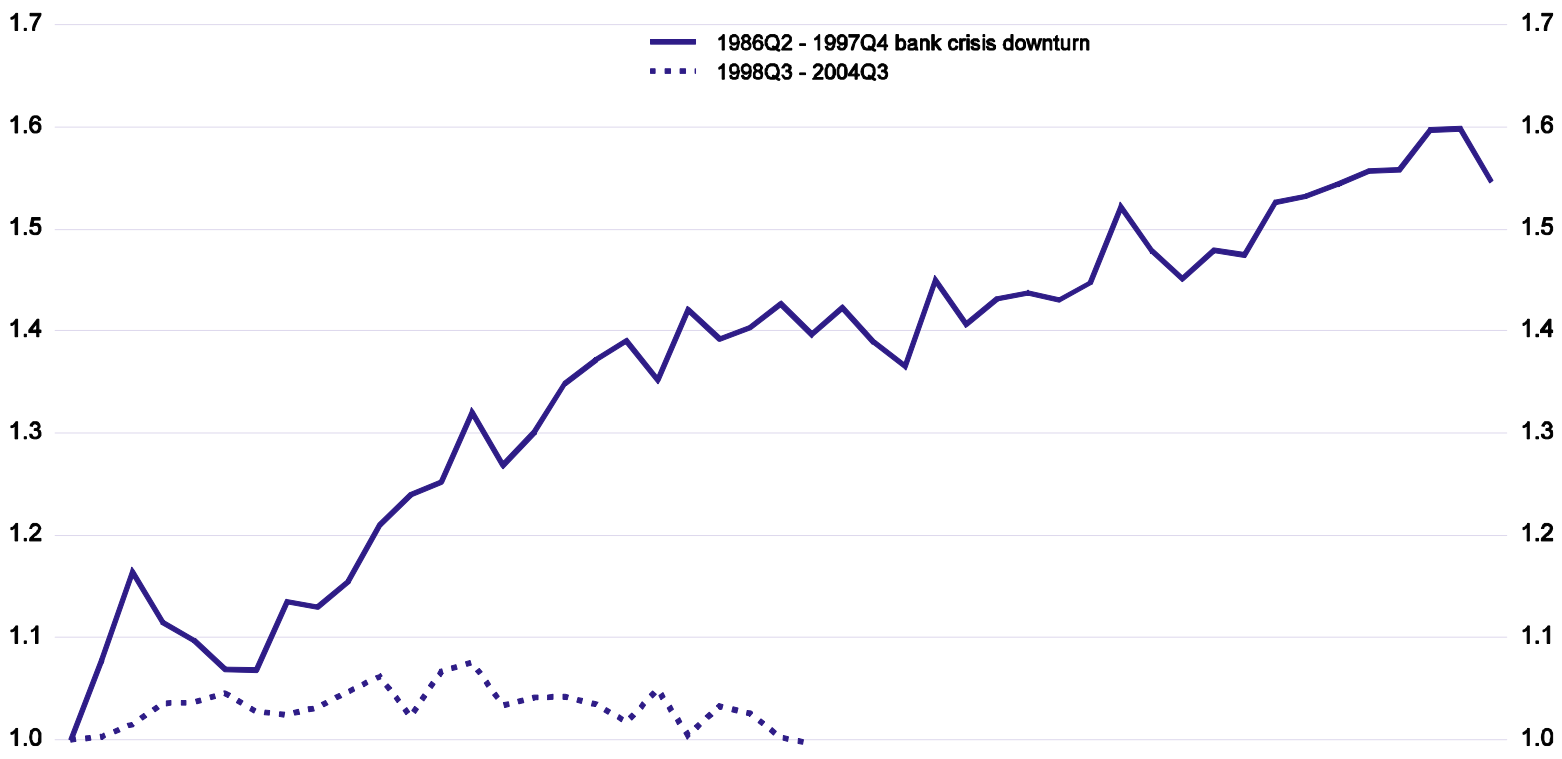

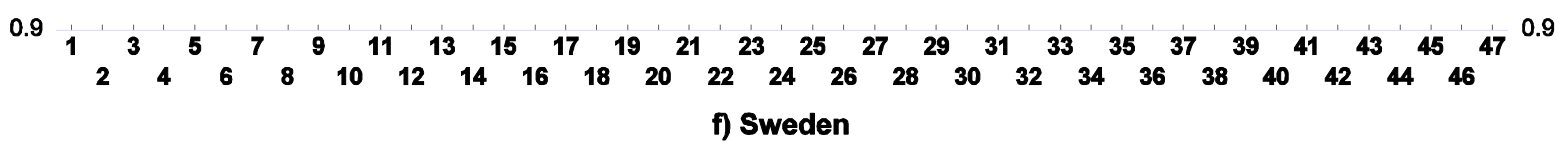

1.7

- 1989Q4 - 1998Q3 bank crisis downturn

\# . 1975Q1 - 1979Q2

1.6

- - 1980Q1 - 1984Q1

1.5

1.4

1.3

1.2

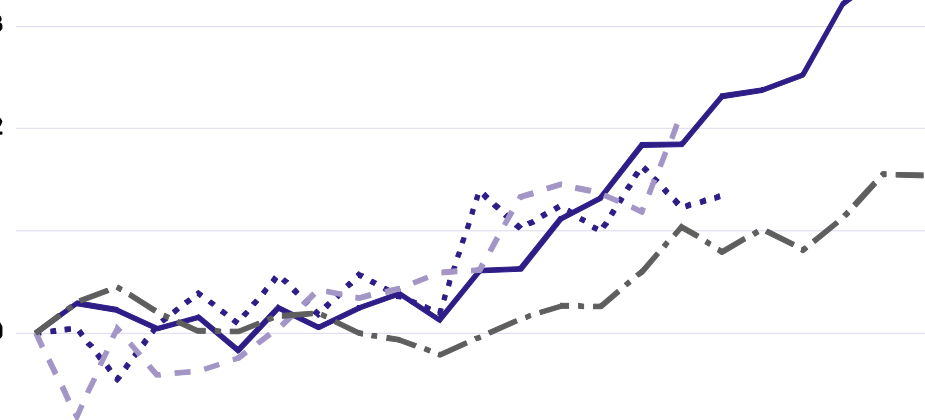

1. Real export relative to real GDP, normalised so that this ratio equals unity at the cyclical peak prior to the downturn. Source: OECD Economic Outlook 84 database. 
Table 4. Fiscal positions following a banking crisis

Peak to Trough

\begin{tabular}{|c|c|c|c|c|c|c|c|c|c|}
\hline & $\begin{array}{l}\text { Bank crisis } \\
\text { downturn }\end{array}$ & $\begin{array}{c}\text { Expenditure } \\
\text { Average of } \\
\text { other } \\
\text { downturns }\end{array}$ & Difference & $\begin{array}{l}\text { Bank crisis } \\
\text { downturn }\end{array}$ & $\begin{array}{c}\text { Revenue } \\
\text { Average of } \\
\text { other } \\
\text { downturns }\end{array}$ & Difference & $\begin{array}{l}\text { Bank crisis } \\
\text { downturn }\end{array}$ & $\begin{array}{l}\text { Fiscal Balance } \\
\text { Average of } \\
\text { other } \\
\text { downturns }\end{array}$ & Difference \\
\hline Spain & 7.0 & 3.8 & 3.1 & 5.9 & 2.4 & 3.5 & -2.5 & -2.0 & -0.5 \\
\hline United States & 1.0 & 4.5 & -3.6 & 1.6 & -0.7 & 2.3 & 1.2 & -5.0 & 6.3 \\
\hline Finland & 19.5 & 4.1 & 15.4 & 4.5 & 1.7 & 2.8 & -15.4 & -2.4 & -13.0 \\
\hline Japan & 5.1 & 4.5 & 0.6 & -0.8 & 4.4 & -5.1 & -5.3 & 1.3 & -6.5 \\
\hline Sweden & 11.0 & 5.7 & 5.4 & -2.6 & 3.0 & -5.6 & -14.7 & -3.7 & -10.9 \\
\hline \multirow[t]{3}{*}{ Norway } & 6.4 & -1.6 & 8.0 & 0.6 & 2.3 & -1.6 & -6.8 & 4.2 & -11.0 \\
\hline & \multicolumn{3}{|c|}{ Cyclically Adjusted Balance } & \multicolumn{3}{|c|}{ Gross Government Debt } & & & \\
\hline & $\begin{array}{l}\text { Bank crisis } \\
\text { downturn }\end{array}$ & $\begin{array}{c}\text { Average of } \\
\text { other } \\
\text { downturns }\end{array}$ & Difference & $\begin{array}{l}\text { Bank crisis } \\
\text { downturn }\end{array}$ & $\begin{array}{c}\text { Average of } \\
\text { other } \\
\text { downturns }\end{array}$ & Difference & & & \\
\hline Spain & -0.9 & 2.3 & -3.2 & & 13.6 & & & & \\
\hline United States & 2.8 & -4.6 & 7.4 & 10.3 & 0.5 & 9.8 & & & \\
\hline Finland & -6.1 & -0.6 & -5.4 & 34.5 & 2.4 & 32.1 & & & \\
\hline Japan & -1.3 & & & 61.1 & 16.8 & 44.3 & & & \\
\hline Sweden & -7.2 & -0.1 & -7.1 & 27.3 & 7.8 & 19.5 & & & \\
\hline Norway & -4.2 & -0.4 & -3.9 & -9.7 & 10.8 & -20.5 & & & \\
\hline
\end{tabular}

Trough to Zero

\begin{tabular}{|c|c|c|c|c|c|c|c|c|c|}
\hline & $\begin{array}{l}\text { Bank crisis } \\
\text { downturn }\end{array}$ & $\begin{array}{l}\text { Expenditure } \\
\text { Average of } \\
\text { other } \\
\text { downturns }\end{array}$ & Difference & $\begin{array}{l}\text { Bank crisis } \\
\text { downturn }\end{array}$ & $\begin{array}{c}\text { Revenue } \\
\text { Average of } \\
\text { other } \\
\text { downturns }\end{array}$ & Difference & $\begin{array}{l}\text { Bank crisis } \\
\text { downturn }\end{array}$ & $\begin{array}{l}\text { Fiscal Balance } \\
\text { Average of } \\
\text { other } \\
\text { downturns }\end{array}$ & Difference \\
\hline Spain & -0.6 & -1.9 & 1.2 & 0.6 & -0.7 & 1.3 & 2.3 & 2.3 & 0.0 \\
\hline United States & -2.5 & -1.2 & -1.3 & 0.8 & 0.5 & 0.3 & 3.4 & 1.7 & 1.7 \\
\hline Finland & -11.0 & 0.4 & -11.4 & -1.9 & -0.1 & -1.9 & 10.3 & -0.2 & 10.5 \\
\hline Japan & -0.5 & 0.6 & -1.1 & 1.1 & 0.0 & 1.2 & 5.5 & -1.5 & 7.0 \\
\hline Sweden & -9.2 & -2.0 & -7.2 & -0.7 & -0.5 & -0.2 & 12.9 & 1.7 & 11.2 \\
\hline \multirow[t]{3}{*}{ Norway } & -8.3 & -2.0 & -6.3 & -1.6 & 2.5 & -4.1 & 7.2 & 4.8 & 2.4 \\
\hline & \multicolumn{3}{|c|}{ Cyclically Adjusted Balance } & \multicolumn{3}{|c|}{ Gross Government Debt } & & & \\
\hline & $\begin{array}{l}\text { Bank crisis } \\
\text { downturn }\end{array}$ & $\begin{array}{l}\text { Average of } \\
\text { other } \\
\text { downturns }\end{array}$ & Difference & $\begin{array}{l}\text { Bank crisis } \\
\text { downturn }\end{array}$ & $\begin{array}{c}\text { Average of } \\
\text { other } \\
\text { downturns }\end{array}$ & Difference & & & \\
\hline Spain & 0.5 & 4.1 & -3.6 & & 4.1 & & & & \\
\hline United States & 2.3 & -1.2 & 3.5 & -6.9 & -1.2 & -5.7 & & & \\
\hline Finland & 3.8 & -0.4 & 4.2 & 9.2 & -0.4 & 9.6 & & & \\
\hline Japan & 2.5 & 0.0 & 2.5 & 18.5 & 0.0 & 18.5 & & & \\
\hline Sweden & 6.0 & 1.7 & 4.2 & 6.1 & 1.7 & 4.4 & & & \\
\hline Norway & 1.9 & 1.5 & 0.4 & 3.6 & 1.5 & 2.1 & & & \\
\hline
\end{tabular}

Note: All figures are reported as the difference between the percentage change in the component and the percentage change in GDP. Except for the real exchange rate where the percentage change is reported. The top of the table analyses changes from the time of the peak output gap prior to the downturn until the trough in the output gap during the downturn. The lower half analyses the changes from the trough of the downturn to the time the output gap is closed again.

Source: OECD Economic Outlook 84 database; and OECD calculations. 


\section{Evidence of effects on potential output growth is mixed}

22. The calculations of lost output previously reported in Table 1 will understate (perhaps greatly) the true output losses if the banking crisis also adversely affects potential output growth. This could occur through a variety of channels, including a reduction in trend productivity growth through permanently impairing the efficient allocation of capital or permanently raising the cost of capital. Other studies suggest that this might be the case given the finding that a full recovery of output to the projected trend level of GDP extended prior to the crisis is rare (Cerra and Saxena, 2008). However, as these authors acknowledge, such estimates tend to overestimate the loss if there has been a boom prior to the crisis. On the other hand, deep economic downturns are usually associated with increased intensity of structural reform measures (OECD, 2007), so that a banking crisis may eventually be beneficial for long-run potential growth.

23. Identifying the effect of banking crises on potential or trend growth is fraught with difficulties. This is not only because measuring potential output is difficult and subject to error, but also because there are multiple influences on potential growth and because the effect of the banking crisis is impossible to isolate. However, because the OECD's method of calculating potential growth uses a production function approach (Beffy et al., 2006) it is possible to decompose any change in potential growth into a number of components which may help to judge whether any change in potential growth can plausibly be attributed to the banking crisis. For example, any change in potential growth which was due to a change in demographic factors could not plausibly be attributed to the effects of a banking crisis.

24. A comparison of potential growth in the five and ten years prior to the onset of a banking crisis downturn with the same period of time following it provides little evidence of a systematic effect on potential growth, although a number of different cases can perhaps be identified (Table 5). Japan is the only country for which there is evidence of lower potential growth both five and ten years after the banking crisis downturn. A decomposition of the change in potential growth suggest that this is partly due to demographic factors (i.e. a slower growth in the population of working age), but that over the longer horizon there is a fall in trend labour productivity growth following both weaker total factor productivity growth and weaker capital deepening. Conversely there is no evidence of either a fall in either trend labour productivity or total factor productivity for any of the other countries considered. One possible explanation is that the resolution of the banking crisis in Japan took a long time with many "zombie" banks kept alive through regulatory forbearance, with the resulting impairment of the financial system leading to the misallocation of capital with damaging consequences for trend productivity growth. Capital deepening was more generally affected during banking downturns except for the United States and Sweden. This is related to the lack of business investment during that period.

\section{Although a rise in structural unemployment may temporarily reduce potential growth}

25. The three Nordic countries represent a different case. Following the banking crises in the Nordic countries there is some evidence of a fall in potential growth in the five years following the onset of the downturn, but not over a longer horizon of ten years. The main cause of this deterioration in potential growth over the five-year horizon is a reduction in potential employment growth and a rise in the structural unemployment rate (Figure 5). Conversely there is little evidence of any deterioration in either trend labour productivity or total factor productivity. The rise in structural unemployment may be attributable to the severity of the recession in the early 1990s interacting with relatively rigid institutional labour market settings (Blanchard and Wolfers, 2000). For example, in Finland there was a massive increase in unemployment which led to a dramatic increase in the use of an unemployment pathway to early retirement, which was available in the 1980s, but was only extensively used following the recession of the 1990s (Koskela and Uusitalo, 2003). 
26. Finally, in the case of the United States there is no evidence of any deterioration in potential output growth either as a result of a rise in structural unemployment or because of a deterioration in trend productivity growth. The former result may reflect the absence of rigidities in labour and product markets which give rise to hysteresis-type effects. Interpreting the latter result is difficult because the second half of the 1990s was also the beginning of the period of a pick-up in trend productivity growth usually attributed to the more intensive application of ICT technologies which may disguise any adverse effect resulting from the banking crisis downturn.

Table 5. Potential growth following a banking crisis

contribution to potential output growth

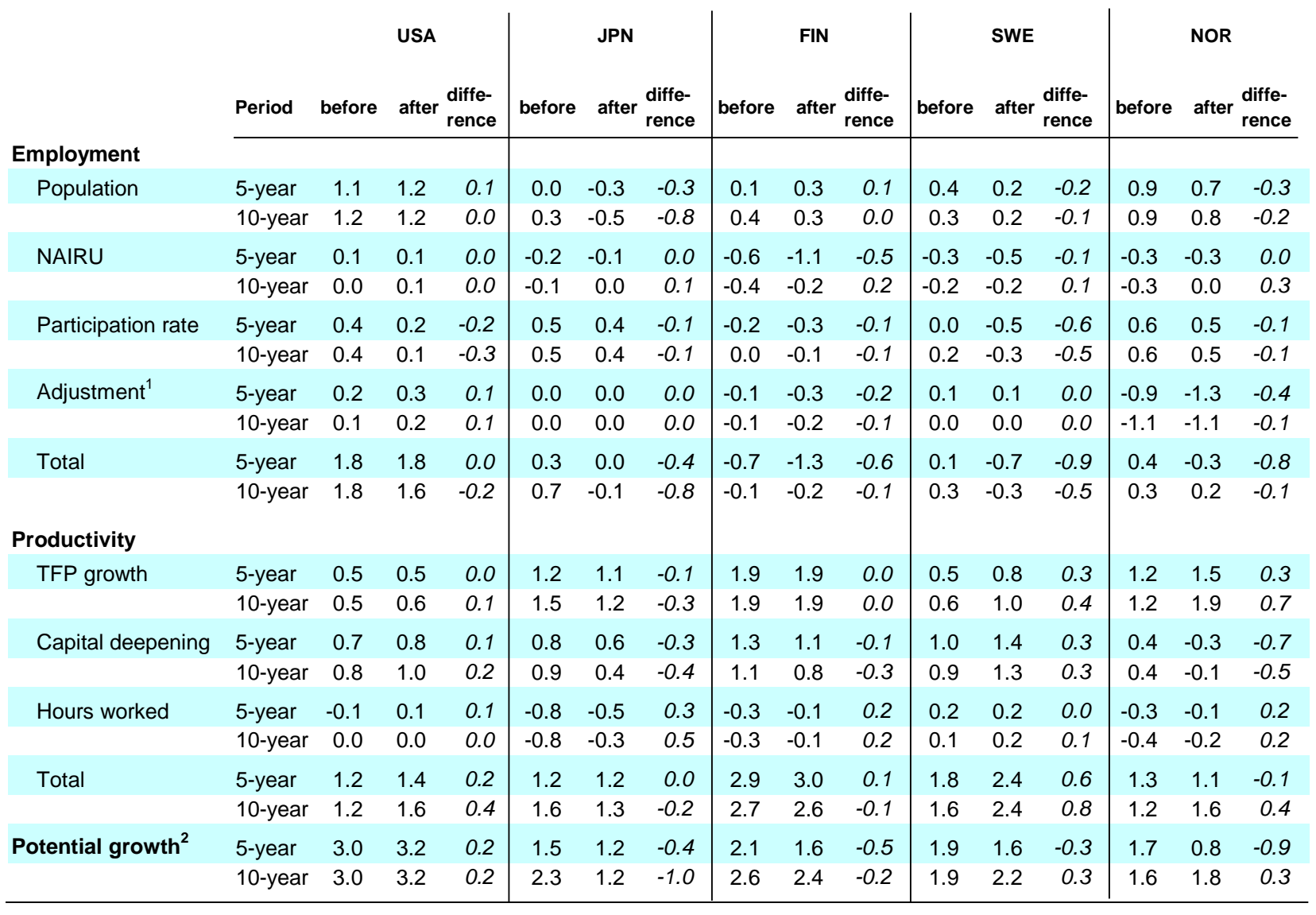

Note: Potential growth in the 5 (10) year period prior to the onset of the downturn is compared with the 5 (10) years immediately following it. For Norway, the potential refers to the business sector only.

1. Adjustment refers for all countries except Norway to the statistical adjustment between the national account and the labour force survey when measuring employment. For Norway, this is the contribution from public employment and employment in the oil sector to the business potential.

2. Potential growth is the sum of potential employment growth and productivity growth.

Source: OECD Economic Outlook 84 database; and OECD calculations. 
Figure 5. Unemployment during a banking crisis downturn

Actual and structural unemployment rate (\% of labour force)

United States
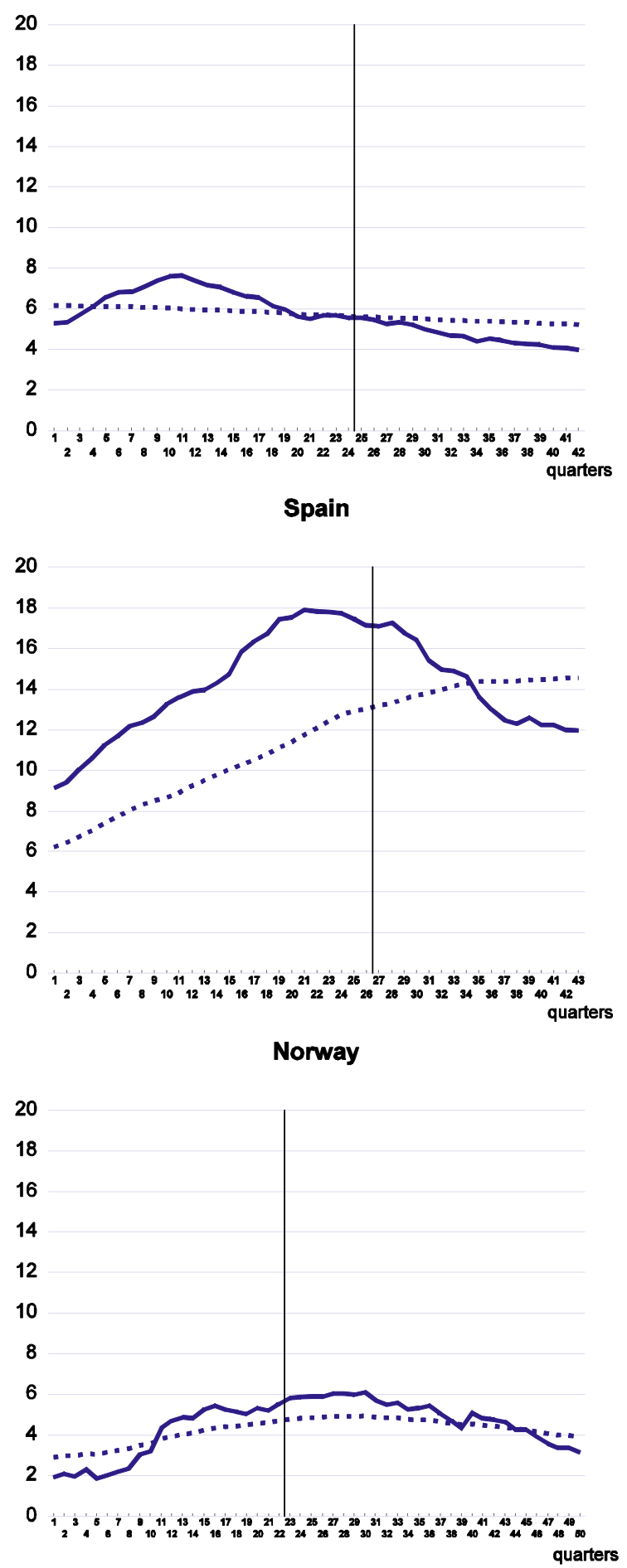

Japan

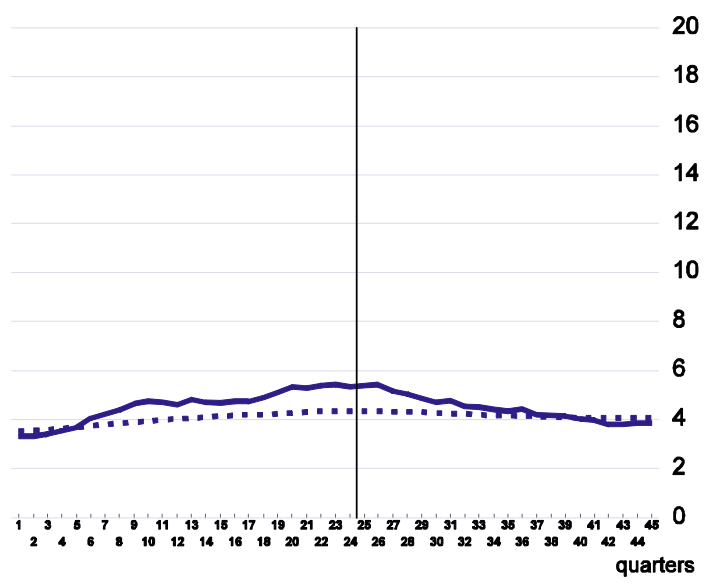

Finland

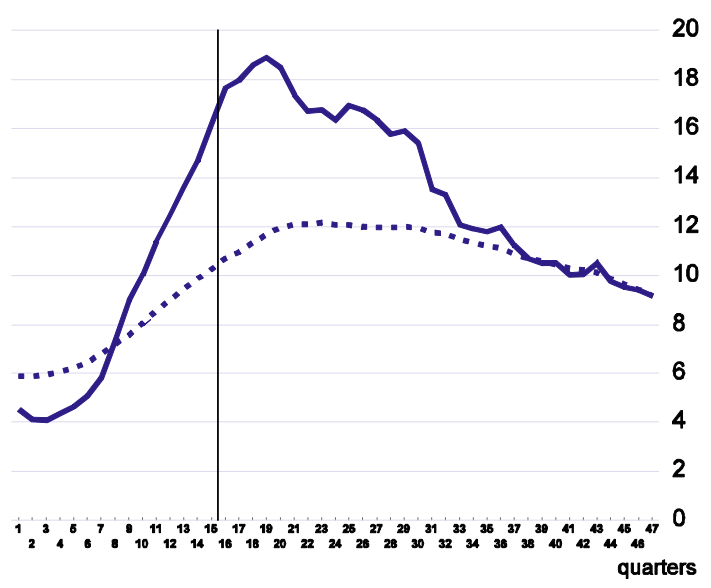

Sweden

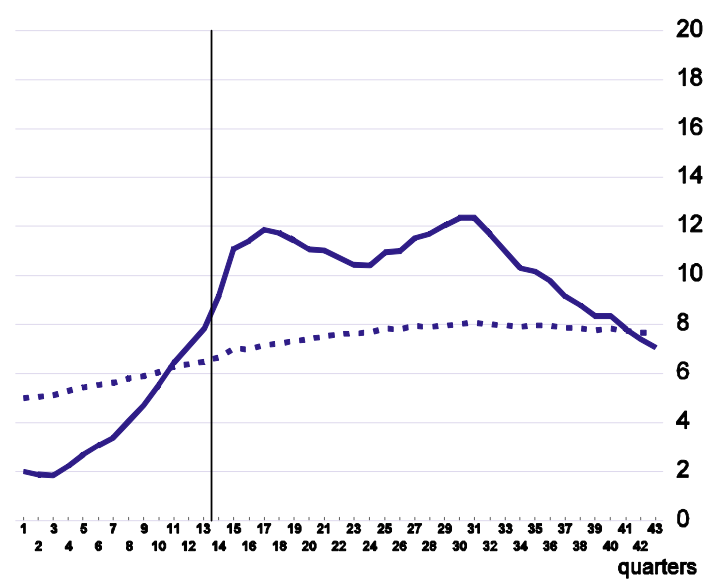

Note: The vertical line identifies the trough of a downturn following a banking crisis. The first quarter corresponds to the cyclical peak prior to the downturn.

Source: OECD Economic Outlook 84 database. 
ECO/WKP(2009)24

\section{BIBLIOGRAPHY}

Beffy, P-O., P. Ollivaud, P. Richardson, and F. Sédillot (2006), "New OECD methods for supply-side and medium-term assessments: a capital services approach", OECD Economics Department Working Paper, No. 482.

Blanchard, O. and J. Wolfers (2000), "The Role of Shocks and Institutions in the Risk of European Unemployment: the Aggregate Evidence", Economic Journal, No. 110.

Bernanke, B., C. Lown and B. Friedman (1991). "The Credit Crunch," Brookings Papers on Economic Activity, No. 2.

Bernanke, B. and M. Gertler (1987) "Financial Fragility and Economic Performance ". NBER Working Paper Series, No 2318.

Bernanke, B. and M. Gertler (1995). "Inside the Black Box: The Credit Channel of Monetary Policy Transmission," Journal of Economic Perspectives, No. 9.

Bernanke, B. (2004), Essays on the Great Depression, Princeton University Press.

Cerra, V. and S.C. Saxena (2008), "Growth Dynamics: The Myth of Economic Recovery", American Economic Review, Vol. 98, No. 1.

Dotsey, M. and A. Kuprianov (1990), "Reforming Deposit Insurance: Lessons from the Savings and Loan Crisis", Federal Reserve Bank of Richmond Economic Review, March/April.

Englund, P. (1999), “The Swedish Banking Crisis: Roots and Consequences”, Oxford Review of Economic Policy, No. 15.

Fukao, M. (2003), “Japan's Lost Decade and its Financial System”, World Economy, Vol. 26, No. 3.

Fukao, M. (2007), "Financial Crisis and the Lost Decade", Asian Economic Policy Review, No. 2.

Hoshi, T. and A.Kashyap (2004), "Japan's Financial Crisis and Economic Stagnation", Journal of Economic Perspectives, Vol. 18, No. 1.

International Monetary Fund (IMF) (2008), "Financial Stress and Downturns", World Economic Outlook, October, Washington D.C.

Kashyap, A. and J. Stein (1995). "The Impact of Monetary Policy on Bank Balance Sheets," CarnegieRochester Conference Series on Public Policy, No. 42.

Koskela, E. and R. Uusitalo (2003), "The Unintended Convergence: How the Finnish Unemployment Rate Reached the European Level”, Labour Institute for Employment Research Discussion Paper, No 188. 


\section{ECO/WKP(2009)24}

Laeven, L. and F. Valencia (2008), "Systemic Banking Crises: A New Database”, IMF Working Paper, No. 224.

Nyberg, P. and V. Vihriälä (1993), "The Finnish Banking Crisis and Its Handling”, Bank of Finland Discussion Papers, Vol. 8/93.

OECD (2007), Chapter 7 in Going for Growth 2007, OECD, Paris.

Reinhart, C.M. and K.S. Rogoff (2008), "Is the 2007 US Sub-Prime Financial Crisis So Different? An International Historical Comparison", American Economic Review, No. 98.

Reinhart, C.M. and K.S. Rogoff (2008a), "The Aftermath of Financial Crises", Paper prepared for the American Economic Association Meetings, 3 January 2009.

Sheng, A. (1996), "Bank Restructuring in Spain, 1977-85" in Bank Restructuring, Lessons from the 1980s, World Bank, Washington DC.

Turner, D. (1995), "Speed Limit and Assymmetric Inflation Effects from the Output Gap in the Major Seven Economies”, OECD Economic Studies, No. 24, Vol. 1.

Warf, B. and J. Cox (1996), "Spatial Dimensions of the Savings and Loan Crisis", Growth and Change, No. 27. 
ECO/WKP(2009)24

\section{WORKING PAPERS}

The full series of Economics Department Working Papers can be consulted at www.oecd.org/eco/Working_Papers/

682. Adjusting housing policies in Slovakia in light of euro adoption (March 2009) Felix Hüfner

681. Achieving fiscal flexibility and safeguarding sustainability the case of Slovakia (March 2009) Isabell Koske

680. Raising flexibility of the Slovak economy during the catch-up phaseDo Latin American central bankers behave non-linearly? The experience of Brazil, Chile, Colombia and Mexico

(March 2009) Isabell Koske

679. Do Latin American central bankers behave non-linearly? The experience of Brazil, Chile, Colombia and Mexico

(February 2009) Luiz de Mello, Diego Moccero and Matteo Mogliani

678. Enhancing educational performance in Australia

(February 2009) Vassiliki Koutsogeorgopoulou

677. Quantifying the effect of financial conditions in the euro area, Japan, United Kingdom and United States

(February 2009) Stéphanie Guichard, David Haugh et David Turner

676. Taking stock of existing structural policy and outcome indicators/ Un inventaire des indicateurs structurels de politique et de performance

(February 2009) Davide Furceri and Annabelle Mourougane

675. Stabilization Effects of Social Spending: Empirical Evidence from a Panel of OECD Countries (February 2009) Davide Furceri

674. Fiscal Convergence, Business Cycle Volatility and Growth (February 2009) Davide Furceri

673. Boosting Productivity in Korea's service sector (February 2009) Randall S. Jones

672. Sustaining growth in Korea by reforming the labour market and improving the education system (February 2009) Randall S. Jones and Masahiko Tsutsumi

671. Reforming the tax system to promote economic growth and cope with rapid population ageing (February 2009) Randall S. Jones

670. Financial market stability: Enhancing regulation and supervision (February 2009) Jeremy Lawson, Sebastian Barnes and Marte Sollie 
669. Overcoming the financial crisis

(February 2009) Andrea De Michelis

668. Financial crises: past lessons and policy implications

(February 2009) Davide Furceri and Annabelle Mourougane

667. Reforms to open sheltered sectors to competition in Switzerland

(February 2009) Andrés Fuentes

666. Raising education outcomes in Spain

(February 2009) Andrés Fuentes

665. Health care reform in the United States

(February 2009) David Carey, Bradley Herring and Patrick Lenain

664. The role of $R \& D$ and technology diffusion in climate change mitigation: new perspectives using the WITCH model

(February 2009) Valentina Bosetti, Carlo Carraro, Romain Duval, Alessandra Sgobbi and Massimo Tavoni

663. Long-run GDP growth framework and scenarios for the world economy

(January 2009) Romain Duval and Christine de la Maisonneuve

662. Realising South Africa's employment potential

(January 2009) Geoff Barnard

661. Making the most of Norwegian schools

(January 2009) Romina Boarini

660. Can the financial sector continue to be the main growth engine in Luxembourg?

(January 2009) Arnaud Bourgain, Patrice Pieretti and Jens Høj

659. Fiscal policy responsiveness, persistence, and discretion

(December 2008) António Afonso, Luca Agnello, Davide Furceri

658. The economics of climate change mitigation: policies and options for the future

(December 2008) Jean-Marc Burniaux, Jean Chateau, Romain Duval and Stéphanie Jamet

657. Maximising Mexico's gains from integration in the world economy

(December 2008) David Haugh, Roselyne Jamin and Bruno Rocha

656. How do taxes affect investment and productivity? An industry-level analysis of OECD countries (December 2008) Laura Vartia

655. Strategies for countries with favourable fiscal positions

(November 2008) Robert Price, Isabelle Joumard, Christophe André and Makoto Minegishi

654. Monetary transmission mechanism in Central and Eastern Europe: Surveying the Surveable

(November 2008) Balázs Égert and Ronald MacDonald 